\title{
Major shear zones of southern Brazil and Uruguay: escape tectonics in the eastern border of Rio de La plata and Paranapanema cratons during the Western Gondwana amalgamation
}

\author{
C. R. Passarelli • M. A. S. Basei - K. Wemmer • \\ O. Siga Jr $\cdot$ P. Oyhantçabal
}

Received: 11 February 2010/ Accepted: 8 August 2010/Published online: 8 September 2010

(C) The Author(s) 2010. This article is published with open access at Springerlink.com

\begin{abstract}
The Mantiqueira Province represents a series of supracrustal segments of the South-American counterpart formed during the Gondwana Supercontinent agglutination. In this crustal domain, the process of escape tectonics played a conspicuous role, generating important NE-N-Strending lineaments. The oblique component of the motions of the colliding tectonic blocks defined the transpressional character of the main suture zones: Lancinha-Itariri, Cubatão-Arcádia-Areal, Serrinha-Rio Palmital in the Ribeira Belt and Sierra Ballena-Major Gercino in the Dom Feliciano Belt. The process as a whole lasted for $c a$. $60 \mathrm{Ma}$, since the initial collision phase until the lateral escape phase predominantly marked by dextral and subordinate sinistral transpressional shear zones. In the Dom Feliciano Belt, southern Brazil and Uruguay, transpressional event at 630-600 Ma is recognized and in the Ribeira Belt, despite less coevally, the transpressional event occurred between 590 and $560 \mathrm{Ma}$ in its northerncentral portion and between $c a .625$ and $595 \mathrm{Ma}$ in its central-southern portion. The kinematics of several shear zones with simultaneous movement in opposite directions at their terminations is explained by the sinuosity of these
\end{abstract}

C. R. Passarelli $(\bowtie) \cdot$ M. A. S. Basei · O. Siga Jr Instituto de Geociências, Universidade de São Paulo, Rua do Lago, 562, São Paulo 05508-080, Brazil

e-mail: crpass@usp.br

\section{K. Wemmer}

Geowissenschaftliches Zentrum der Universität, University of Göttingen, Abt. Isotopengeologie Goldschmidtstr.

3, 37077 Göttingen, Germany

P. Oyhantçabal

Departamento de Geología, Facultad de Ciencias,

Universidad de la República, Iguá 4225 ,

11400 Montevideo, Uruguay lineaments in relation to a predominantly continuous westward compression.

Keywords Mantiqueira Province - Gondwana agglutination - Suture zones - Escape tectonics . Metamorphic-deformational events

\section{Introduction}

Magmatic, metamorphic and structural records of superposed orogeneses can be observed in southeastern Brazil. These records reflect the collage of distinct terranes in a process that culminated with the consolidation of Western Gondwana during the Neoproterozoic-Eopaleozoic transition. The episodes associated with this agglutination are subduction, continental collision and late-collisional transcurrent movements. The latter, which were responsible for the dissipation of great part of the energy generated during the collisional processes, caused the lateral displacement of crustal masses by means of an escape or lateral extrusion tectonic process.

In the Himalayas, this process can be observed as a result of the collision between the Indian and Asian continental tectonic plates, leading to the eastward sinistral transport along the Tian Shan and several other faults (Molnar and Tapponnier 1975; Yeats and Lillie 1991; Jacobs and Thomas 2004; Zhang and Wang 2007). Another important example is the Alpine orogeny, when in its younger stages, especially during the Pliocene-Quaternary, dextral transcurrent faults caused the lateral escape of major crustal fragments (Ratschbacher et al. 1991; Picha 2002; Brückl et al. 2007; Tomljenovic et al. 2008).

The evolution of the accretionary Andean belt, developed in the western margin of the South-American 
continent with significant destruction of oceanic crust, was responsible for the generation of north-south trending, narrow, linear, typical accretionary chains, and also for the creation and deformation of arc-related settings and continental reactivation, with several peaks of orogenic activity since the Upper Triassic (Mégard 1987; Hervé et al. 1987; Stern and Kilian 1996; Ramos and Aleman 2000). Transcurrent movements associated with collision are common during continental evolution. Tectonic escape has been an element in the continental evolution along the whole Earth's geologic history record, leading to (1) rifting and formation of rift-basins accompanied by crustal thinning; (2) late penetrative transcurrent zones that separate mountain chains by shearing and juxtapose sectors that have no connection in transversal section; (3) compressional mountain chains and associated foreland basins (Sengor et al. 1985; Burke and Sengor 1986).

In the Gondwana Supercontinent agglutination, the escape tectonics process took place by means of important lineaments, mainly trending $\mathrm{NE}-\mathrm{N}-\mathrm{S}$, in the fold belts associated with the collision of the São Francisco, Kalahari, Paranapanema and Río de La Plata cratons (Brito Neves and Cordani 1991; Campos Neto and Figueiredo 1995; Hackspacher and Godoy 1999; Brito Neves et al. 1999). In this context, the structural framework and kinematic patterns of the shear zones are discussed, including brittleductile reactivations, thermal-metamorphic pattern characterization, and, when possible, the determination of the absolute age of the metamorphic-deformational events. The focus of this work will be on the Arcádia-Areal (Rio de Janeiro), Lancinha-Cubatão-Itariri and Serrinha-Rio Palmital Shear Zones of the central-southern portion of the Ribeira Belt (São Paulo and Paraná states) and on the Sierra Ballena-Cordilheira-Major Gercino shear belt in the Dom Feliciano Belt, as well as on the significance of these mega-shear zones in the Gondwana agglutination context.

\section{Geological background}

The NE-SW-trending Mantiqueira Province (Almeida et al. 1981) stretches out for ca. 3,000 km along the Atlantic coast, from Punta del Este (Uruguay) to south of Bahia in Brazil (Fig. 1) bordering the São Francisco, Paranapanema and Rio de la Plata/Paraná cratons and surrounding the Luis Alves and Curitiba microplates (Almeida et al. 1981; Brito Neves and Cordani 1991; Cordani and Sato 1999; Mantovani and Brito Neves 2005, and others). It developed from the end of the Neoproterozoic to the beginning of the Paleozoic, during the Neoproterozoic Brasiliano-Panafrican Orogeny, which resulted in the amalgamation of Western Gondwana (Almeida et al. 2000).
This tectonic province includes the Araçuaí, Ribeira, Dom Feliciano and Rocha fold belts, which developed diachronically by the interaction of the São FranciscoCongo, Kalahari, Paranapanema and Rio de La Plata cratons, as well as minor cratonic fragments such as Luis Alves and Curitiba (Almeida et al. 1981; Brito Neves and Cordani 1991; Heilbron et al. 2004; Mantovani and Brito Neves 2005; Silva et al. 2005a). This orogen resulted from the closure of the Adamastor Ocean due to the convergence of the São Francisco-Congo and partially the Rio de La Plata cratons and the amalgamation of several minor terranes such as the Apiaí, Embu, Curitiba/Registro, Luis Alves and Juiz de Fora to the margin of the São Francisco craton.

The ca. 1,500 km-long Ribeira Belt (Hasui et al. 1975; Almeida et al. 1981) is situated in southern Brazil (Fig. 1), extending from south of the Bahia State into the Paraná State. It is the largest geotectonic unit of the Mantiqueira Province (Almeida and Hasui 1984; Silva et al. 2005a). It consists of tectonic domains limited by expressive Neoproterozoic Shear Zones (Fig. 1). In its central-northern portion, the Juiz de Fora, Paraíba do Sul and Coastal terranes stand out. Its southeastern portion is composed of the Embu and Apiaí terranes.

The major geotectonic unit in the southern part of the Mantiqueira Province is represented by the Dom Feliciano Belt (DFB). The tectonic evolution of the DFB is associated with the Neoproterozoic and Early Paleozoic Western Gondwana collage (Fragoso-Cesar 1980; Basei et al. 2000). It forms a roughly NE-SW-trending belt and occupies the entire eastern segment of southern Brazil and Uruguay (Fig. 1). From its southern limit in Uruguay to its termination in Santa Catarina state in Brazil, the DFB is composed of three crustal sectors separated by tectonic contacts: (a) I-type medium to high-K calc-alkaline granitoid rocks of Florianópolis, Pelotas and Aiguá batholiths; (b) Central greenschist to amphibolite-facies metavolcanosedimentary rocks of Brusque, Porongos and Lavalleja groups; and (c) anchimetamorphic sedimentary and volcanic rocks of Itajaí, Camaquã, Arroyo del Soldado and Piriápolis foreland basins.

\section{The Ribeira Belt}

The RB central sector is characterized by a series of thrust faults that developed under amphibolite facies conditions and imprinted a northwestward vergence pointing to the São Francisco Craton (Heilbron et al. 1995; Heilbron and Machado 2003). They evolved to transpressional systems, markedly the Rio Paraíba do Sul Shear Belt (Ebert et al. 1996) (Fig. 1). Southeast in the RB, the Lancinha-Cubatão Shear Zones (L-C) separate the Embu/Apiaí terranes (NW) 


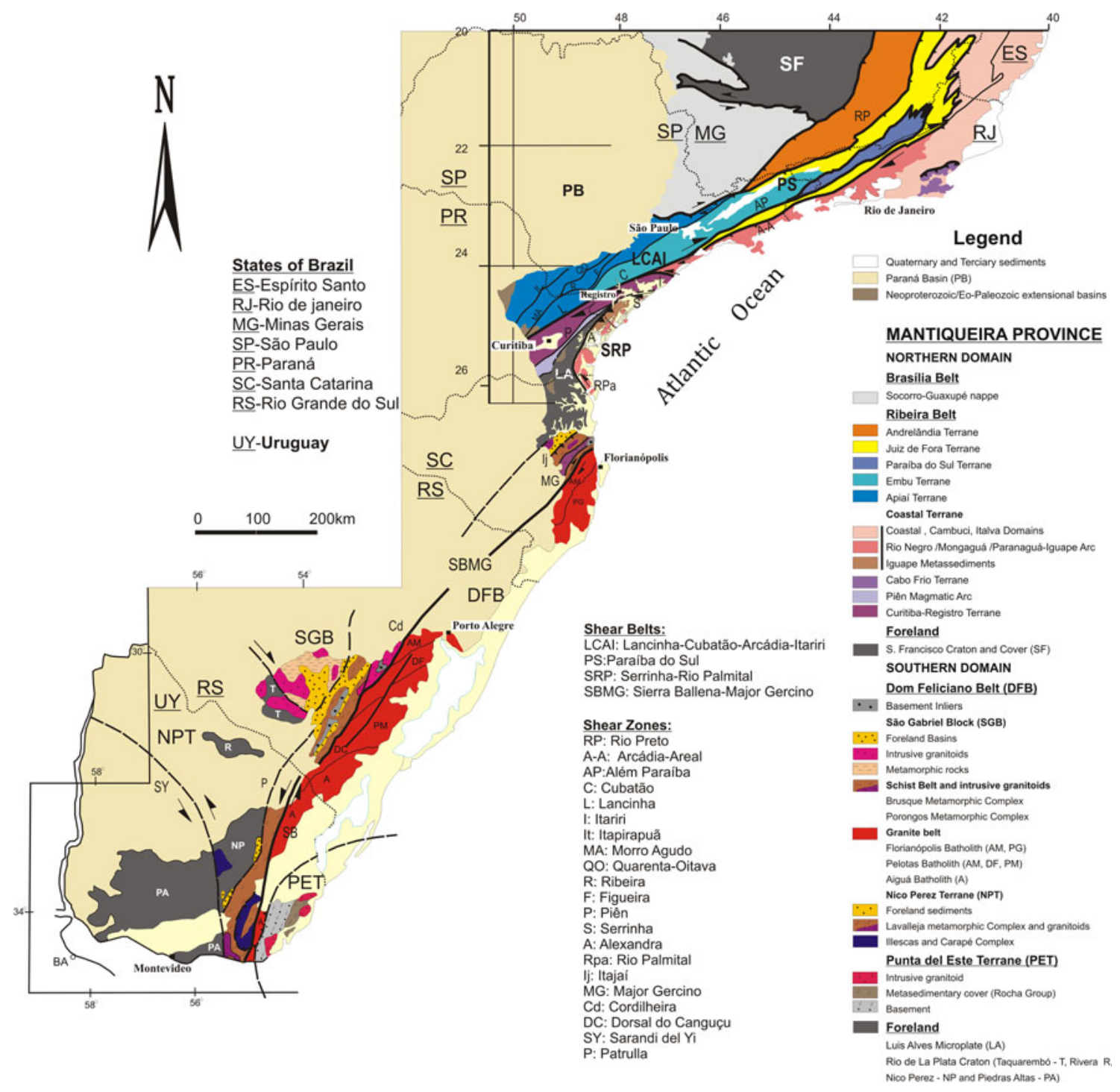

Fig. 1 General outline of the Mantiqueira Province (Brazil-Uruguay) (Simplified from Campos Neto and Figueiredo 1995; Bossi et al. 1998; Basei et al. 1999, 2000; Heilbron et al. 2004; Tupinambá et al. 2007)

from the Curitiba/Registro granitic-gneissic terranes (SE). In turn, the Itariri Shear Zone (I) separates the Curitiba/ Registro terranes from the Coastal Terrane. Southwards, between São Paulo and Paraná states, the Serrinha (S), Alexandra (A) and Rio Palmital (RPa) Shear Zones limit the Coastal Terrane (Fig. 1). They represent mega-structures responsible for the structural framework and compartmentation of distinct Precambrian terranes.

The tectonic compartmentation of the central-northern portion

The RB central-northern portion in Rio de Janeiro, Espirito Santo and Minas Gerais states encompasses four main tectono-stratigraphic terranes denominated as Occidental, Oriental, Paraíba do Sul/Embu, and Cabo Frio, by Heilbron et al. (1995, 2000, 2003, 2004). The first two are separated from one another by the Arcádia-Areal Shear Zone, which is complexly re-folded and steeply to moderately northwestwards dips in the central-southern portion of Rio de Janeiro, and southeastwards in the northeastern portion of that state and south of Espírito Santo (Tupinambá et al. 2007). The Occidental Tectonic Terrane includes the Juiz de Fora and Andrelândia Terranes (Heilbron et al. 1998). The Juiz de Fora Terrane (Fig. 1) is composed of a Paleoproterozoic granulite-facies orthogneisses (Machado et al. 1996) and subordinately by high amphibolite- to granulite-facies metasediments, granites and gneisses. The Andrelândia Terrane (Fig. 1) is composed of Neoproterozoic metasedimentary sequence (Sollner and Trouw 1997), which reached the high-pressure, high amphibolite facies that mainly comprises schists, gneisses, quartzites, 
migmatitic gneisses and calc-silicate rocks. The Paraíba do Sul Terrane (Fig. 1) is characterized by Meso- to Neoproterozoic metasediments (Machado et al. 1996) of the intermediate-pressure, amphibolite facies, which locally underwent partial melting. It consists of gneisses, schists, quartzites, marbles and calc-silicate rocks and is crosscut by syn-tectonic and post-tectonic granitoids. The Coastal Terrane (Fig. 1) includes rocks generated in magmatic arc settings and Neoproterozoic metasediments and was subdivided in the Rio de Janeiro northwestern region in three distinct structural domains: (a) the Cambuci domain (metavolcano-sedimentary sequence with marble and calc-alkaline orthogneisses lenses); (b) the Coastal domain (sediments metamorphosed to the granulite to high amphibolite facies intercalated with impure quartzites and intrusive orthogneisses and metagabbros of the Rio Negro Magmatic Arc); (c) the Italva domain (metavolcanosedimentary sequence with marbles, amphibolites and paragneisses). The Cabo Frio Terrane (Fig. 1) is represented by Paleoproterozoic orthogneisses, tectonically intercalated with supracrustal rocks, metamorphosed to the amphibolite to granulite facies during the Mid-Cambrian.

The tectonic compartmentation

of the south-southeastern portion

The southeastern Ribeira Belt consists of four major tectonic domains limited by significant shear zones associated with Neoproterozoic events. The Embu Terrane is limited to the south from the Registro/Curitiba Terrane by the Cubatão Shear Zone. The Coastal Terrane, represented by the Mongaguá magmatic arc, is limited from the Embu and Registro/Curitiba terranes by the sinistral Itariri Shear Zone, and the Paranaguá magmatic arc from the Registro/ Cutitiba Terrane and the Luis Alves Microplate by the Serrinha-Rio Palmital Shear System (Fig. 1).

The Embu Terrane (Fig. 2), in the southeastern portion of São Paulo State, north of the Cubatão Shear Zone (CSZ), is composed of mica schists, partially migmatized paragneiss, quartzite, fine schists, phyllites and subordinately metabasite and calc-silicate rocks. Calc-alkaline and peraluminous granites (Dantas et al. 1987b) crosscut these units. The first records of magmatic processes in this Terrane date from the Cryogenian (810-780 Ma) and were obtained by zircon U-Pb SHRIMP (Cordani et al. 2002) and by U-Pb ID-TIMS dating (Passarelli et al. 2003, 2008). The metamorphic climax was characterized around 780 Ma by monazite in situ dating (Vlach 2001).

The Apiaí terrane is formed by Mesoproterozoic and Neoproterozoic metavolcano-sedimentary sequences (Basei et al. 2003; Weber et al. 2004; Campanha et al. 2004, 2008; Siga et al. 2009) with intrusive calc-alkaline granitoid rocks (Gimenez Filho et al. 2000; Prazeres Filho et al. 2003) and a series of Paleoproterozoic gneiss-migmatitic nuclei related to the Statherian taphrogenesis (Brito Neves et al. 1995; Cury et al. 2002) limited by shear zones, where the Itapirapuã, Morro Agudo, Ribeira, Figueira and Quarenta Oitava stand out (Fig. 1).

Associated gneissic-migmatitic and granitic rocks predominate in the Mongaguá and Paranaguá-Iguape magmatic arcs of the Coastal Complex. The Mongaguá granitoids have been correlated with the Rio Negro magmatic arc in the Rio de Janeiro State by Passarelli et al. (2004a, 2008) being limited by Cubatão Shear Zone to the northwest and by the Itariri Shear Zone to the south (Fig. 2). Gneiss-migmatitic rocks yielded $\mathrm{U}-\mathrm{Pb}$ zircon ages in the 640-620 Ma range, and late-intrusive granites present zircon TIMS ages around $580 \mathrm{Ma}$ (Passarelli et al. 2003, 2008). The Paranaguá-Iguape domain is largely represented by deformed calc-alkaline granitic rocks of ages between 620 and $570 \mathrm{Ma}$ (Siga et al. 1993; Cury et al. 2008), which are sometimes intruded by two-mica leucogranites. As probable remains of host rocks, meta-rhythmites, quartzites and fine schists with apparent metamorphic grade increase southwards occur.

The Registro-Curitiba Terrane is limited from supracrustal rocks to the north (Embu and Apiaí) and from Mongaguá magmatic arc rocks by the Cubatão-Itariri Shear Zone and from the Paranaguá domain rocks by the Serrinha Shear Zone (Fig. 2). It is formed by Paleoproterozoic gneissic-migmatitic rocks $(2.1-2.2 \mathrm{Ga})$ strongly deformed during the Neoproterozoic (600-580 Ma). Its cover is composed of meta-limestones, meta-sandstones and metapelites and intermediate-greenschist- to amphibolite-grade metamorphic sequence represented by quartzites, schists and paragneisses. The Juréia Massif garnet-biotite gneisses and the cordierite gneisses outcropping north of the Serrinha Shear Zone and correlated with the Cachoeira Sequence show two metamorphic records, an older one around $750 \mathrm{Ma}$ (Passarelli et al. 2007, 2008), interpreted as the metamorphic peak of the paragneissic rocks, and a younger one, around $595 \mathrm{Ma}$, responsible for the neoformation and recrystallization of monazite, associated with intense granitic magmatism of similar age occurring in this domain. This terrane is separated from the Luis Alves Microplate by the Piên Suture Zone, characterized by the presence of magmatic arc roots of $615 \mathrm{Ma}$ and ophiolitic remains of $630 \mathrm{Ma}$ (Harara et al. 1997; Basei et al. 2000).

\section{The Ribeira Belt tectonics}

There exist several tectonic models for the Ribeira Belt central portion that indicate southeastward or northwestward subduction, followed by the collision of the São Francisco, Congo and Paranapanema cratons (Porada 1979; Basei et al. 1992; Trompette 1994; Trouw et al. 2000; Heilbron and Machado 2003). Along its length, the Ribeira 


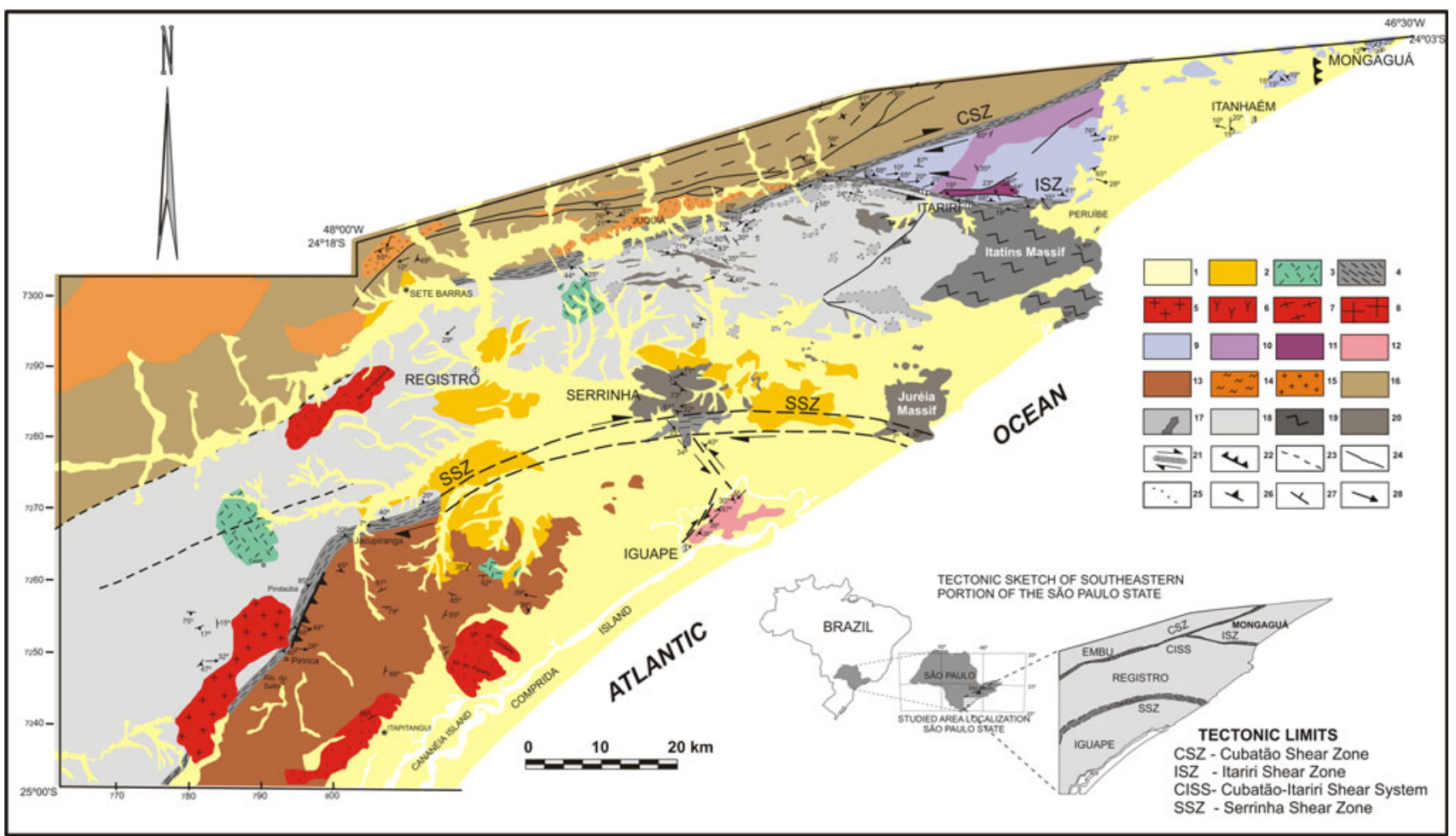

Fig. 2 Geological map of southeastern São Paulo State (modified from Passarelli C 2001). 1 Quaternary sediments. 2 Tertiary sediments. 3 Juquiá Alkaline Complex (Cretaceous). 4 CISS and SSZ: mylonitic rocks. Serra do Mar Granitic Suite: 5 Itapitangui 6 Serra do Cordeiro 7 Serra do Votupoca 8 Guaraú. Mongaguá Domain: 9 Itariri-type granites and gneiss-migmatitic rocks. 10 Areado Granite. 11 Ribeirão do Óleo Granite. Iguape Domain: 12 Iguape

Belt shows a clear change in the deformation regime. The southeastern portion is characterized by transpressional deformation with coeval or slightly diachronous northwestward thrusting that evolves to predominantly dextral orogen-parallel transcurrent movements during the final stages (Trompette 1994; Hackspacher and Godoy 1999; Egydio-Silva et al. 2002; Schmitt et al. 2004; Vauchez et al. 2007). The southern portion is characterized by thrusting of allochthonous units on the São Francisco Craton margin (Cunningham et al. 1998; Campos Neto and Caby 2000; Trouw et al. 2000). This change in the dominant deformation regime is probably associated with the interaction between the Ribeira and Brasília Belts at the São Francisco Craton southern termination (Vauchez et al. 1994; Egydio-Silva et al. 2005).

In the northern portion of the Ribeira Belt, in the interface with the Araçuaí Belt, U-Pb ages of $575 \mathrm{Ma}$ represent the time of metamorphic climax with the generation of leucocratic anatexites, as well as the pre- to syncollisional magmatism (Vauchez et al. 2007). In the RB, central-northern sector the record of four main tectonic phases is better defined: (a) pre-collisional, between 630
Granite. 13 Iguape metasediments. Embu Terrane: 14 Juquiá Granite. 15 Sete Barras Granite. 16 Indiscriminate metasediments. Registro Domain: 17 Granite-gneiss-migmatitic Domain. 18 Gneissic Domain. 19 Itatins Complex. 20 Cachoeira Sequence. 21 Main shear zones. 22 Fault with thrust component 23 Inferred Faults. 24 Lineaments. 25 Gradational geological contact. 26 Mylonitic foliation. 27 Principal foliation. 28 Mineral lineation

and $600 \mathrm{Ma}$, (b) syn-collisional between 590 and $565 \mathrm{Ma}$, late-collisional between 540 and $520 \mathrm{Ma}$ and post-tectonic between 520 and $480 \mathrm{Ma}$ (Heilbron et al. 1995; Machado et al. 1996; Heilbron and Machado 2003). The Juiz de Fora, Andrelândia and Paraíba do Sul terranes were amalgamated to the São Francisco Craton SE border between 605 and $580 \mathrm{Ma}$ (Machado et al. 1996; Heilbron and Machado 2003). With a more recent and independent metamorphicdeformational history, the Cabo Frio Terrane was accreted at the end of the orogenic collage, at $c a$. 530-510 Ma (Schmitt et al. 2004). This domain presents the highestpressure metamorphic paragenesis with kyanite, which differs from the metamorphic pattern predominant in the Ribeira Belt, characterized by high-temperature and lowpressure mineral associations.

In the Embu Terrane, the period between 810 and $780 \mathrm{Ma}$ was characterized as that of the magmatic-metamorphic climax, associated with a convergent tectonic process (Cordani et al. 2000; Vlach 2001). Important calcalkaline magmatism associated with the syn-collisional phase occurred in this sector of the Ribeira Belt between 620 and $610 \mathrm{Ma}$ (Hackspacher et al. 2000; Janasi et al. 
2001, 2003). Lateral escape tectonics with development of several NE-SW-trending shear zones and emplacement of granitic bodies (Hackspacher et al. 2000) occurred around $600 \mathrm{Ma}$ and can be correlated with the late-collisional phase in this sector of the Ribeira Belt (Janasi et al. 2001).

In the Mongaguá Domain of the Coastal Terrane, south-southeastern portion of the Ribeira Belt, four important thermal episodes are recorded: 640; 620-610; 600 and $580 \mathrm{Ma}$. The deformed granites (Itariri-type) and gneissic-migmatitic rocks yielded U-Pb zircon ages of ca. 640 and 620-610 Ma and are probably associated with the Rio Negro magmatic arc-related rocks, in the central part of Ribeira Belt (Tupinambá et al. 2000; Dias Neto et al. 2002). The Itariri-type granites (Fig. 2) reveal a metamorphic overprint of ca. $600 \mathrm{Ma}$, pointed out by $\mathrm{U}-\mathrm{Pb}$ monazite ages. In the central part of Ribeira Belt, the $600 \mathrm{Ma}$ event represented by extensive crustal melting that led to leucogranite generation is also well characterized and marks the end of subduction-related magmatism (Tupinambá et al. 2000; Heilbron and Machado 2003).

The collisional phase intrinsically associated with the juxtaposition of Mongaguá, Embu and Registro blocks is associated with a mean E-W compression and probably occurred around $580 \mathrm{Ma}$ (monazite and zircon U-Pb ages). The syn-collisional magmatism is represented by peraluminous foliated and mylonitic granites that occur as NE-SW elongated plutons (Areado Granite-Fig. 2). The tectono-thermal event near $580 \mathrm{Ma}$ is also recognized in the Paraíba do Sul and Coastal domains in Rio de Janeiro (Machado et al. 1996; Heilbron and Machado 2003).

\section{Major shear zones of the Ribeira Belt: geochronology and structural features}

The Ribeira Belt, a mobile belt that borders the São Francisco, Paranapanema and part of the Rio de La Plata cratons, contains thrusts and transcurrent shear zones. In this chapter, emphasis will be given to the main transcurrent shear zones, resulting from lateral escape tectonics associated with agglutination in this sector of Gondwana. In general, in the areas to be discussed, two main deformation types were recognized: lateral movements (dextral and sinistral transcurrent faulting) and shortening perpendicular to the shear zones, represented by flattening. The Itariri Shear Zone and its close relationship with the Cubatão-Lancinha-Arcádia-Areal system, with records from the north of Paraná to the north of Rio de Janeiro state, will be treated specifically. The main characteristics of the Serrinha-Palmital shearing system will also be discussed.
Lancinha-Itariri-Cubatão-Arcádia-Areal Shear System

This shear system can be subdivided in two main segments that separate distinct tectonic compartments. It represents suture zones with ductile to ductile-brittle characteristics, developed in the greenschist to low amphibolite facies (Fig. 2). The E-W segment is represented by the sinistral Itariri Shear Zone (ISZ) that strikes predominantly N85W/ 70NE and has 400- to 700-m of width, composed mainly of protomylonites and mylonites (Sadowski et al. 1978; Silva et al. 1981; Egydio-Silva 1981; Dantas et al. 1987b; Gimenez Filho et al. 1987; Passarelli et al. 2004a, 2008). The NE segment represented by the Lancinha-Cubatão Shear Zone cluster around N70E-N75E/sub-vertical (Sadowski 1984; Dantas et al. 1987b; Passarelli et al. 2004a, 2008).

In the north of the Ribeira Belt, this shear zone was former referred as the Além Paraíba-Cubatão-Lancinha Shear Zone (Sadowski 1984; Machado and Endo 1993). In the Paraná and São Paulo states represents a shear zone of ca. 300- to 1,500-m in width, composed mainly of mylonites, protomylonites and phyllonites, predominant dextral movement with brittle-ductile reactivations (Gimenez Filho et al. 1987; Sadowski and Motidome 1987; Sadowski 1991; Passarelli et al. 2004a, 2008).

Southeast of São Paulo State, between Itariri and Juquiá (Fig. 2), two important deformation phases were identified in the Cubatão and Itariri Shear Zones by means of a systematic structural study of the mylonitic rocks. The first deformational phase, of ductile nature, is associated with sinistral movements of a N85W-trending shear zone, with intermediate to strong dips to $\mathrm{N}-\mathrm{NE}$ and two sets of stretching lineations (Passarelli 2001). The first one dipping E-NE is scarcely preserved (west of Itariri city, Fig. 2), thus giving a thrust component toward the SW. The second one plunging moderately to $\mathrm{NW}$ is compatible with an extensional component of the shear zone. Local folds with hinge lines parallel to the second stretching lineations were also observed. The second arrangement of the stretching lineations possibly represents an extensional movement resulting from stress release of the juxtaposition of the Embu and Registro terranes (Passarelli 2001; Passarelli et al. 2005). The first phase represents the peak metamorphic conditions in the evolution of the Itariri Shear Zone, which reached the amphibolite facies, and is characterized by intense feldspar recrystallization and the presence of well-developed polycrystalline quartz ribbons (Boullier and Bouchez 1978; Hongn and Hippertt 2001). To this deformational phase are associated mainly oblate to prolate ellipsoids (Passarelli 2001) with main shortening direction around N20E-N40E (Fig. 3). This deformational phase records sinistral deformation at amphibolite facies 


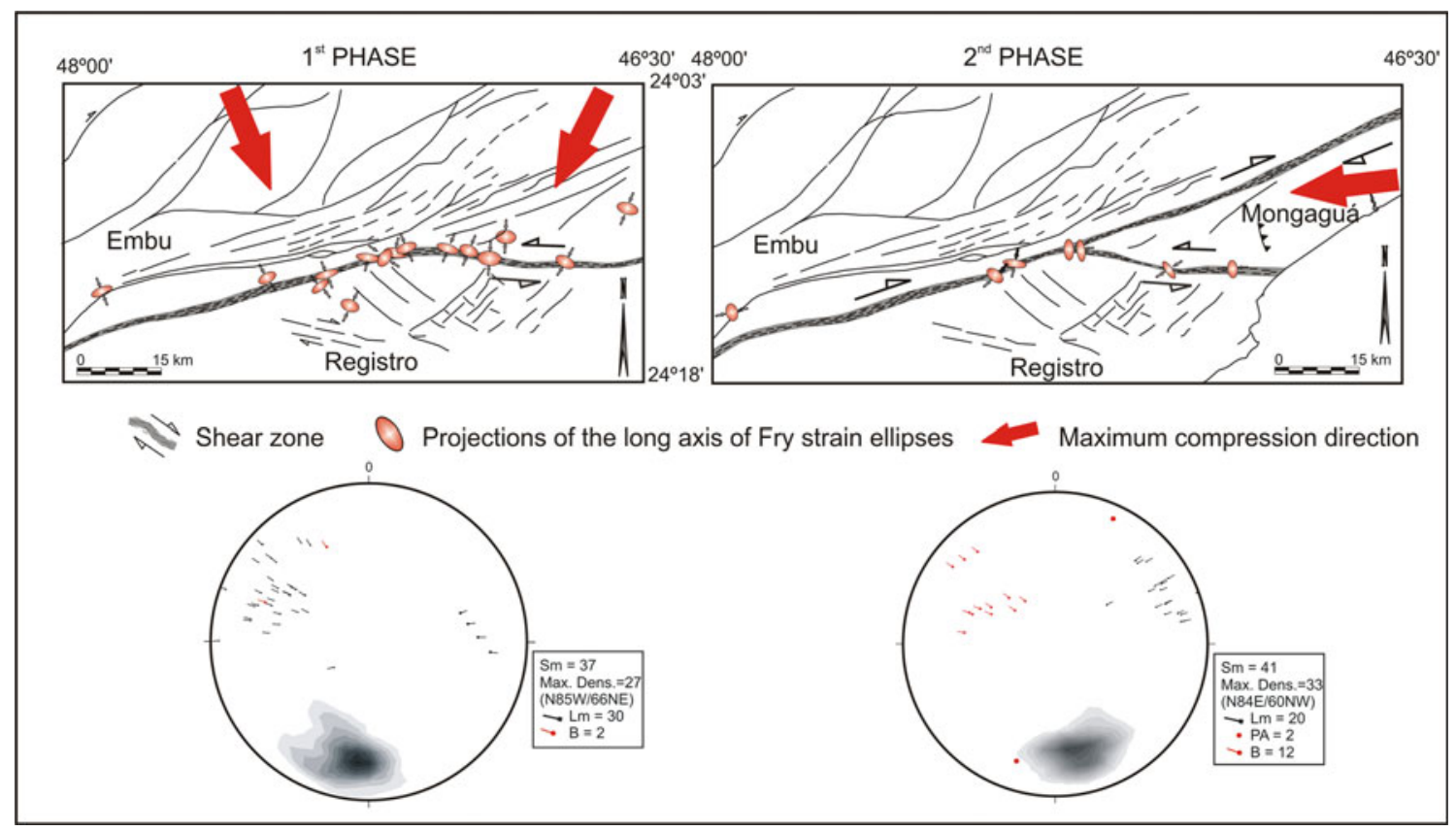

Fig. 3 Deformation phases in the Itariri Shear Zone with the projections of the long axis of Fry strain ellipses. Maximum compression direction and respective structural data plotted in equal area lower hemisphere Schmidt-Lambert stereographic projection.

metamorphic mineral association, corroborated by geothermobarometric analysis (Passarelli unpublished data).

The second deformational phase, with ductile/ductilebrittle characteristics, is associated with an average E-W compression (deformation ellipses with major axis striking $\mathrm{N}-\mathrm{S}$ ), which caused a main sinistral strike-slip displacement with a modest thrust component toward the SW in the 'Itariri E-W branch' (recorded by the oblate deformation ellipsoids) and a dextral strike-slip displacement in the 'Cubatão NE branch' (Fig. 3). This deformational phase associated with sinistral movement in the 'Itariri E-W branch' is represented by a N84E-trending shear zone, with intermediate to strong dips to N-NW and a gently plunging NE mineral stretch lineation and associated folds with axes perpendicular to the mineral stretch lineation. Finite strain ellipsoid analyses show the total prevalence of oblate-type ellipsoids associated with this deformational phase (Passarelli 2001; Passarelli et al. 2005). In this context, the NE-SW 'Cubatão branch', slightly younger than the 'E-W Itariri branch', probably restarted moving in the western portion of the E-W branch, which records a dextral movement close to the junction of the ramifications. From the petrographic data, this phase did not exceed the greenschist facies. This phase is associated with the formation of a 'wedge' characterized by the junction of the 'Itariri and Cubatão branches', forming the Cubatão-Itariri Shear System (CISS), where the Mongaguá terrane is juxtaposed against two other terranes: Embu and Registro (Fig. 3).
Number of data points $(n)$ shown. $S m$ Poles to mylonitic foliation, $P A$ poles to fold planes, $\mathrm{Lm}$ mineral stretching lineation; $B$ fold axis. The terranes are discriminated

In the Lancinha Shear Zone, N60E-striking sinistral movements preceded the dextral shear is also reported (Pierin et al. 2009), but further studies are needed to investigate the correlation between these movements and those recorded in the Cubatão-Itariri Shear System (CISS).

Sinistral reactivation in more brittle conditions is evidenced in CISS by mylonitic foliation and the generation of striations. Later sinistral brittle faulting, trending approximately $\mathrm{N} 40 \mathrm{E}$ and NW-trending fracturing are also observed, clearly crosscutting the mylonitic foliation. In the central part of the Ribeira Belt, one of the most important structures is the Rio Paraíba do Sul Shear Belt (Fig. 4) that comprises a anastomosing network of NE-SW trending ductile shear zones extending over $1,000 \mathrm{~km}$ of the southeastern coast of Brazil (Ebert et al. 1996).

One of the most important shear zones of this complex system is the granulite-facies mylonites of the deep-crustal Além Paraíba Shear Zone that limits the Paraíba do Sul terrane and partly makes the boundary of the Juiz de Fora and Embu terranes (Fig. 1). It is a $10 \mathrm{~km}$ wide, dextral strike-slip vertical shear zone occurring in the north-central portion of Rio de Janeiro State, oriented N70E and N40E, in the southern and northern portions, respectively, and is slightly oblique to the regional orogenic trend (EgydioSilva and Mainprice 1999; Hippertt et al. 2001; EgydioSilva et al. 2002). It represents a mega-scale C' shear band that acted as a strain transfer shear zone accommodating the orogen-normal contraction components in a transpressional 
Fig. 4 Schematic structural map of the southern portion of Ribeira-Araçuaí Belt showing the NE-SW-trending dextral transpressional Rio Paraíba do Sul Shear System and adjacent areas with dominant kinematics ( $L$ Lancinha, $C$ Cubatão, $I$ Itariri, $A-A$ Arcádia-Areal Shear Zones). Modified from Vauchez et al. (1994); Ebert et al. (1996); Egydio-Silva and Mainprice (1999)

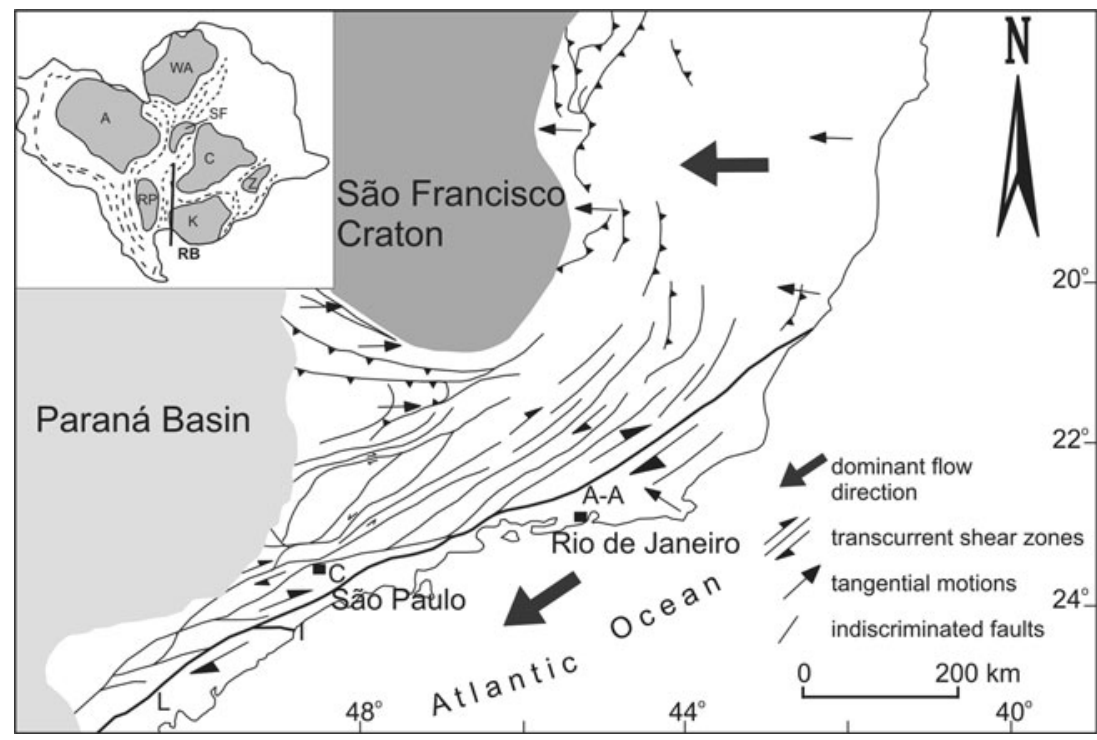

regime (Egydio-Silva et al. 2002). This tectonic structure has been considered as a dextral shear zone developed in response to a transpressional regime, which produced wide mylonitic zones (Ebert et al. 1991; Machado and Endo 1993; Vauchez et al. 1994). Determination of stress directions has confirmed the kinematics of this deformation regime, suggesting that pure shear was as important as simple shear (Egydio-Silva and Mainprice 1999; EgydioSilva et al. 2002). Many authors correlated the Além Paraíba Shear Zone with Cubatão-Lancinha Shear Zone (Fiori 1985a; Machado and Endo 1994; Ebert and Hasui 1998; Campanha and Sadowski 1999; Silva et al. 2005a).

However, in this work, we stress out our opinion that the Cubatão Shear Zone, which is a suture zone because it separates domains with totally distinct tectonic evolutions, continues northeastwards, into the Rio de Janeiro state, as the so-called Arcádia-Areal Shear Zone or Central Tectonic Limit (Almeida et al. 1998; Heilbron et al. 2004), and not as the Além Paraíba or Paraíba do Sul Shear Zone, located ca. $20 \mathrm{~km}$ northwest (Fig. 1).

The Arcádia-Areal Shear Zone, which represents the continuity of the Cubatão Shear Zone in the Ribeira Belt central sector, Rio de Janeiro State, strikes N65E and steeply to moderately dips northwestwards and locally southeastwards with a maximum in N60E/48 NW and a sub-horizontal and directional stretching lineation around N33E $/ 24^{\circ}$ (Almeida et al. 1998). The Arcádia-Areal Shear Zone corresponds to the tectonic limit (Almeida et al. 1998) between the Oriental and Occidental terranes (Heilbron et al. 2000; Trouw et al. 2000), reaching ca. $3 \mathrm{~km}$ in thickness.

Divergent kinematic indicators are found in the ArcádiaAreal Shear Zone (Almeida et al. 2006). While asymmetric porphyroclasts indicate a sense of shear top down to NE in the metasediments, characterizing a dextral distensional transport, the sigma structures in orthogneisses of the Coastal Terrane indicate top up to SW characterizing a sinistral compressional transport. The authors propose two distinct explanations: a previous west-to northwestward thrusting followed by transpressional dextral shearing that rotates the stretching lineation to NE, or a previous west-to northwestward thrusting and later transtensive dextral shear zone that formed a NE stretching lineation. In both cases, the deformation was partitioned, concentrated in the "softer" and anisotropic metasedimentary rocks, and preserving the more isotropic and "harder" igneous rocks (Almeida et al. 2006). The finite deformation ellipsoids determined for this shear zone are oblate, confirming the importance of pure shearing. The greenschist metamorphic grade observed in the Cubatão Shear Zone contrasts with that of mylonitic rocks of the shear system in the Rio de Janeiro State, which reaches the lower-medium amphibolite or even the granulite facies (Machado et al. 1996; Egydio-Silva et al. 2002).

In the Paraná State, the Lancinha Shear Zone, which is the natural continuity of the Cubatão Shear Zone, shows associated folding, sinistral transtensional reactivation, and is characterized by rare mylonitic rocks and a brittle anastomosed aspect (Fiori 1985a, b; Soares 1987; Salamuni et al. 1993; Salamuni 1995; Fassbinder et al. 1994). The Lancinha Fault would reflect, at the surface, an older and deeper fault, represented by the Cubatão Lineament, reactivated under brittle-ductile conditions (Fiori 1985a; Fassbinder et al. 1994).

\section{Serrinha: Rio Palmital Shear System}

The Serrinha-Rio Palmital Shear System separates the Paranaguá-Iguape Arc from the Curitiba-Registro and Luis Alves Microplate (Fig. 1). The Serrinha Shear Zone 
(Passarelli 2001) is the northern part of this shear system and changes from a dextral transcurrent ramp in the easternmost portion (Juréia) to a dextral lateral-oblique ramp in the central-western portion (Serrinha and Pariquera-Açu) and to a frontal ramp in the western portion (Piririca area-Fig. 2). It is associated with the juxtaposition of the Paranaguá-Iguape and the Registro-Curitiba Terrane.

In general, the strike of the mylonitic foliation varies from $c a$. N60W/NE low dip in the eastern portion, with a gently plunging mineral stretch lineation, grading in the central portion around E-W with low- to intermediateangle stretching lineations, and around N80E/NW low dip with low-angle lineations and around N20E/SE intermediate dip with down-dip stretching lineations in the westernmost portion. The transcurrent Alexandra and Palmital Shear Zones represent the southern continuity of this system, indicating sinistral kinematics with oblique component characterized by the co-existence of strike-slip and down-dip lineations (Siga et al. 1993; Cury et al. 2008). Therefore, this system delineates along its whole area a tectonic wedge composed of the Paranaguá Terrane, with preferential westward transport (Fig. 2). The different shear zones that compose this system represent the partition of the main strain associated with the collision of the Paranaguá Terrane with other domains to the west, in the site of the Luis Alves Microplate.

The easternmost sector of Serrinha Shear Zone (SSZ) affects the Juréia paragneissic rocks of Cachoeira Sequence, Registro-Curitiba terrane, with the mylonitic foliation characterized by strong stretching of the quartz-feldspatic portions. The mylonitic foliation has a predominantly N40W-N65W strike and dips $35^{\circ}-65^{\circ}$ to NE, with a subhorizontal to gently $\mathrm{NE}$ plunging stretching lineation. In this east sector, the Serrinha Shear Zone represents a dextral lateral ramp (Passarelli et al. 2007). Mylonitic rocks of granitic composition of the central sector of the SSZ are imbricated with granulite-facies metasedimentary rocks of Cachoeira Sequence. The mylonitic foliation shows a general strike around E-W and is associated with a predominant dextral movement with an important pure shear component. The coaxial component is characterized mainly by the presence of dextral and sinistral kinematic indicators, symmetric porphyroclasts and results of Fry analysis (Passarelli 2001). In this area, the Serrinha Shear Zone presents a conspicuous, $1 \mathrm{~km}$-thick, N35W-trending, SE-dipping ramification, (Fig. 2) where sinistral movement is observed associated with a NW thrust component. A frontal thrust ramp with $\sim \mathrm{N} 60 \mathrm{~W}$ transport is characterized in the westernmost sector (Fig. 2) by a N20E striking moderately SE-dipping mylonitic foliation, carrying a welldefined down-dip mineral lineation defined by stretched-out feldspar aggregates.
Ages of main deformation and cooling episodes

In the Lancinha-Itariri Shear Zone, the first deformational phase is associated with the juxtaposition of the Embu and Registro domains. The period between 620 and $600 \mathrm{Ma}$ is suggested in this work as the most probable for this movement and is recorded in rocks of both terranes. In Embu Terrane, protomylonitic granites yielded U-Pb ages of metamorphic epidote around $598 \mathrm{Ma}$ (Passarelli et al. 2008) obtained for the Juquiá Granite (Fig. 5a) and in monazite around $620 \mathrm{Ma}$ (Passarelli et al. 2008) obtained for the Sete Barras Granite (Fig. 5b). A metamorphic overprint at ca. $600 \mathrm{Ma}$ in granite-gneissic rocks is record in zircon overgrowths (U-Pb SHRIMP, unpublished data) and from protomylonitic granite monazites by $\mathrm{U}-\mathrm{Pb}$ ID-TIMS dating from Registro Terrane (Fig. 6).

The oldest age of the second deformation episode, which generated the wedge formed by the Itariri and Cubatão Shear Zones, is $583 \pm 3 \mathrm{Ma}$ (Fig. 7), defined by a concordant $\mathrm{U}-\mathrm{Pb}$ age of a needle-shaped zircon from a mylonite of the Cubatão Shear Zone northern branch and a lower intercept of the Areado and Ribeirão do Óleo Granites of Mongaguá Domain (Fig. 2) and interpreted as syn-kinematic to the Cubatão-Itariri Shear Zone main movement (Passarelli et al. 2008).

According to Machado et al. (1996), the metamorphic climax in the Central Ribeira Belt was reached between 590 and $565 \mathrm{Ma}$ (zircon, monazite and titanite ages). It represents the record of an important tectono-thermal event characterized by partial melting, intrusion of granitic rocks and remobilization of basement gneisses. They correspond to early WNW thrusting that started before $589 \pm 8 \mathrm{Ma}$ (monazite and titanite ages) and to the development of dextral shear zones. A slightly lower-grade metamorphic imprint was recorded during the development of the dextral transcurrent shear zones before 535-527 Ma (zircon, monazite and titanite $\mathrm{U}-\mathrm{Pb}$ ages).

In the Serrinha-Rio Palmital Shear System, in situ U-Pb ages using conventional TIMS analyses (Passarelli et al. 2009) and EPMA chemical dating (unpublished data) were obtained. Monazite crystals extracted from mylonitic granitic rocks and from the Juréia Massif mylonitic paragneisses, respectively, located in the central and eastern portions of the Serrinha Shear Zone, were dated. An average age of $575 \pm 5 \mathrm{Ma}$ (Passarelli et al. 2008) was obtained by both methods (Fig. 8a, b), which is interpreted as the metamorphic peak associated with the movement of the Serrinha Shear Zone, the deformation reaching the amphibolite facies.

Both for the Cubatão-Itariri Shear Zone and the Serrinha Shear Zone, muscovites and biotites extracted from mylonitic rocks analyzed by the $\mathrm{K}-\mathrm{Ar}$ and $\mathrm{Ar}-\mathrm{Ar}$ methods yielded cooling ages (McDougall and Harrison 1999; 


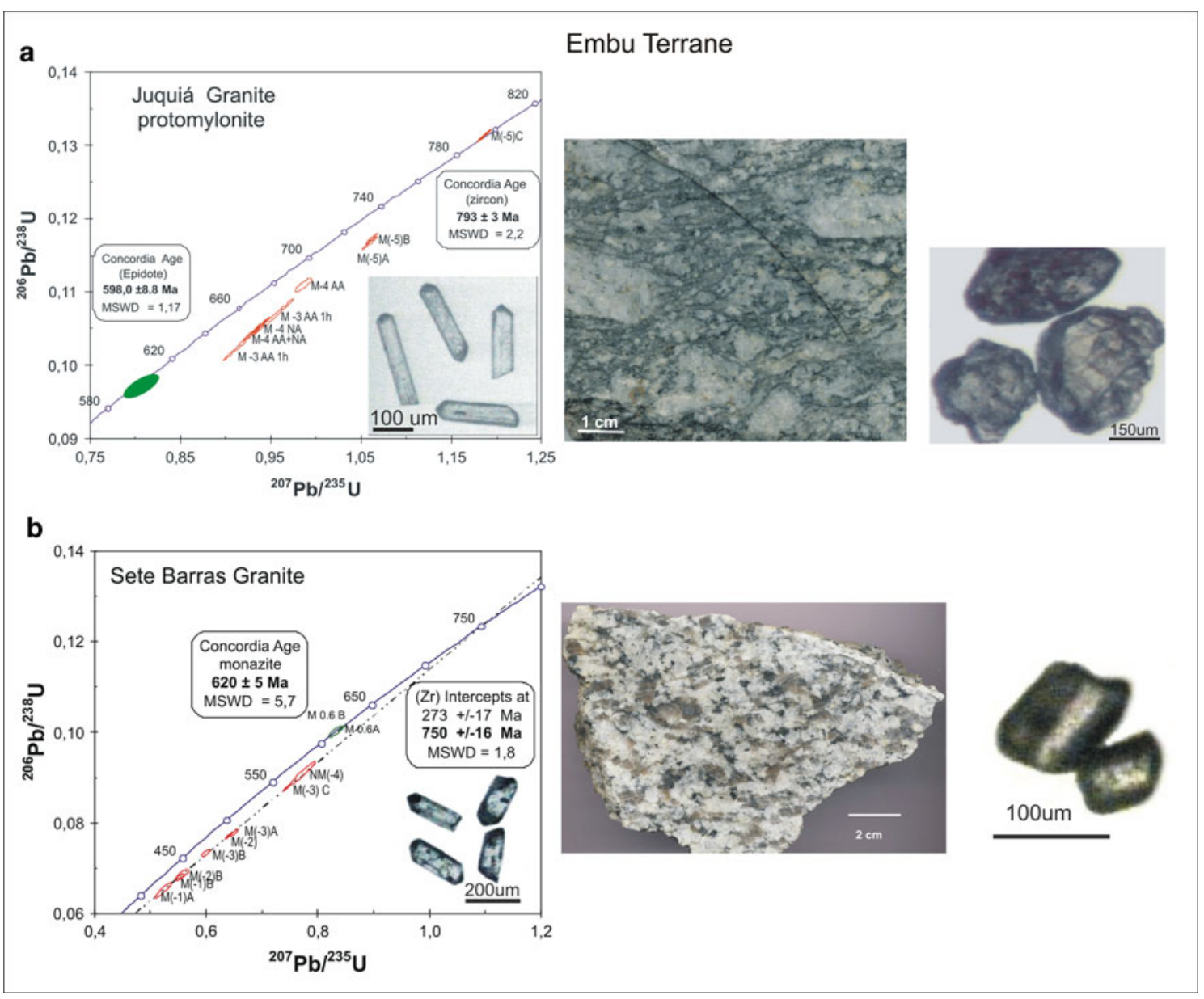

Fig. $5{ }^{206} \mathrm{~Pb} /{ }^{238} \mathrm{U}$ vs. ${ }^{207} \mathrm{~Pb} /{ }^{235} \mathrm{U}$ Concordia diagram of Embu Terrane granites. a Juquiá Granite; b Sete Barras Granite. The crystallization age is defined by zircons and the deformation age by epidote and monazite. The photographs of the samples and respective minerals dated are included

Willigers et al. 2001). The K-Ar ages obtained for fine fractions are systematically younger and are interpreted as referring to very low-temperature processes (around $300^{\circ} \mathrm{C}$ ) associated with subsequent reactivation of the shear zones, causing the generation of very fine-grained materials, which can be dated, sensitive to low- to very low-grade thermal events (Wemmer 1991).

Along the Cubatão-Itariri shear system, for which there are a reasonable number of samples dated, a constancy of $\mathrm{K}-\mathrm{Ar}$ ages between 490 and $500 \mathrm{Ma}$ and $\mathrm{Ar}-\mathrm{Ar}$ ages between 483 and $499 \mathrm{Ma}$ obtained from biotites is observed. These ages are distinct from those obtained from a sample collected at the junction of the ramifications of these shear zones, which yielded ages around $400 \mathrm{Ma}$, suggesting that this area remained heated for a longer time than the others. The K-Ar ages obtained for fine fractions are slightly older in the Itariri Shear Zone, between 395 and $425 \mathrm{Ma}$, than those of the Cubatão Shear Zone, between 


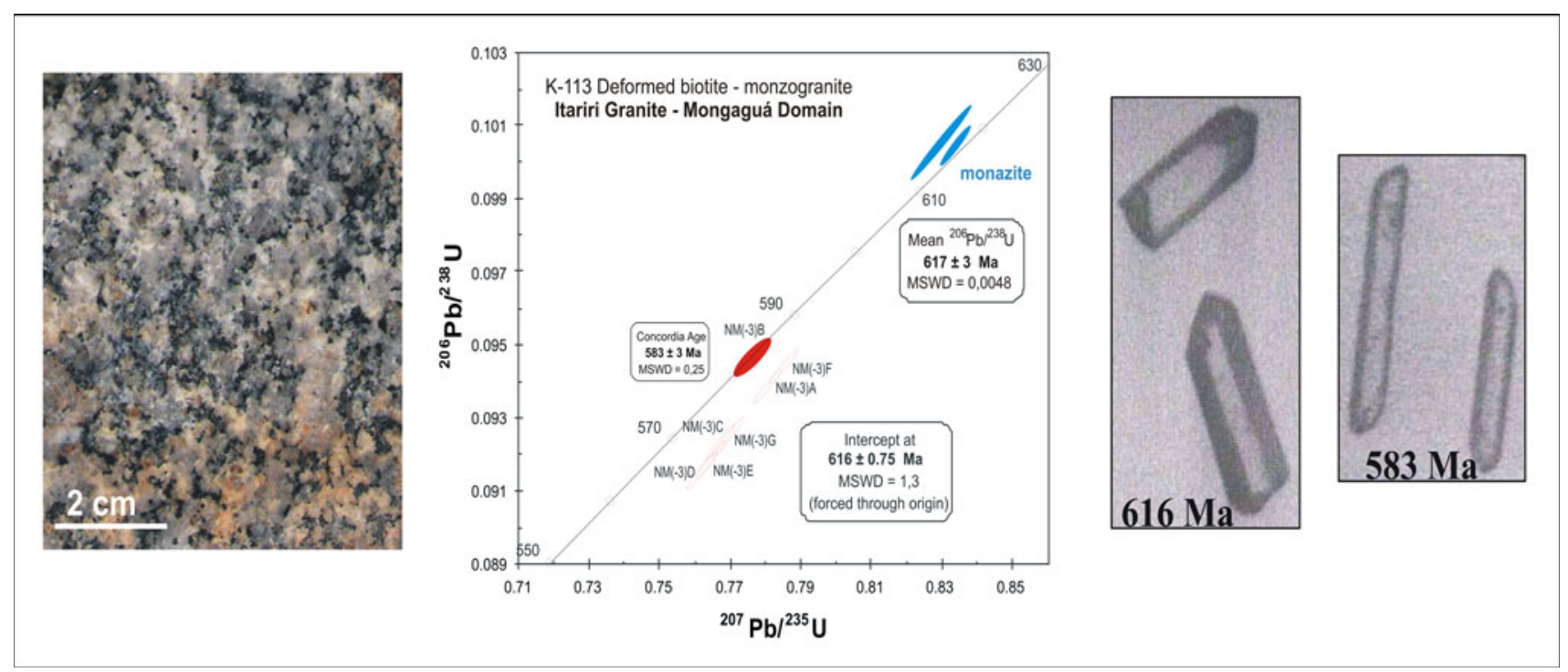

Fig. $7{ }^{206} \mathrm{~Pb} /{ }^{238} \mathrm{U}$ vs. ${ }^{207} \mathrm{~Pb} /{ }^{235} \mathrm{U}$ Concordia diagram of the $617 \mathrm{Ma}$ deformed granite of Mongaguá Domain. The crystallization age is defined by zircons and monazite and the deformation age of $583 \mathrm{Ma}$ by needle-shaped zircons. Photographs of the samples and respective dated minerals are included

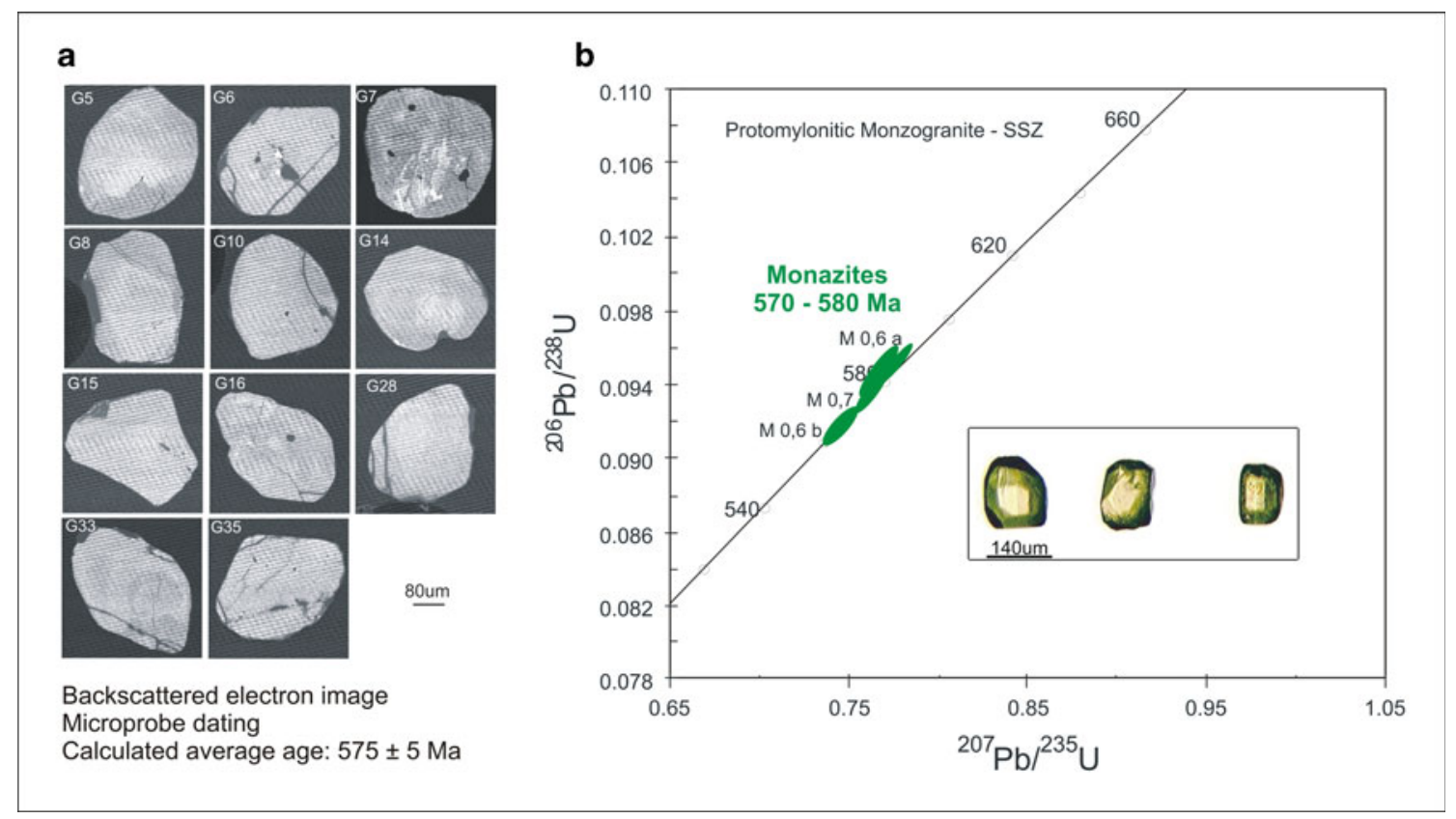

Fig. $8 \mathrm{U}-\mathrm{Pb}$ dating of monazite (protomylonite Serrinha Shear zone). a Backscattered electron image of Microprobe dating monazite grains: -26 analytical spots over the main crystals gave chemical ages in the range between 550 and $599 \mathrm{Ma}$ with an average of

375 and $380 \mathrm{Ma}$. In the Serrinha Shear Zone, the biotite $\mathrm{K}-\mathrm{Ar}$ and $\mathrm{Ar}-\mathrm{Ar}$ ages are distributed between 482 and $495 \mathrm{Ma}$, the muscovite of the eastern sector yielding $501 \pm 5$ Ma. In the western sector of the Serrinha Shear Zone, ages of $575 \mathrm{Ma}$ yielded by muscovites are concordant with the $\mathrm{U}-\mathrm{Pb}$ ages obtained for monazites extracted from a Serrinha Shear Zone protomylonite and represent its
$575 \pm 5$ Ma. b ${ }^{206} \mathrm{~Pb} /{ }^{238} \mathrm{U}$ vs. ${ }^{207} \mathrm{~Pb} /{ }^{235} \mathrm{U}$ Concordia diagram showing data points and error ellipses for concordant populations of monazite with an age range interval 580-570 Ma

main period of movement. The $\mathrm{K}-\mathrm{Ar}$ ages obtained for the fine fractions are distributed between 370 and $425 \mathrm{Ma}$, with older ages being apparently more characteristic in the eastern sector.

Fission-track dating of apatites resulted in important information on the thermal-tectonic evolution of the Cubatão-Itariri Shear System and the Mongaguá and 
Registro terranes, specifically on the low-temperature thermal history, supplying records of the main exhumation events. The uplift of the South-American continent coastal region, associated with the uplift phase of the process that culminated with the continental rupture and opening of the Atlantic (Gallagher et al. 1995; Amaral et al. 1997; Hackspacher et al. 1999, 2004a; Kohn et al. 2002; Tello Sáenz et al. 2003; Godoy et al. 2006; Hackspacher and Tello Sáenz 2006; Hackspacher et al. 2008), is recorded by apatite fission tracks with ages around $120 \mathrm{Ma}$ in rocks of the crystalline basement of the Paraná Basin eastern border (Godoy et al. 2006). Similar values were obtained in the Registro and Mongaguá domains affected by the Cubatão Shear Zone. Neocretaceous cooling ages, around $74 \mathrm{Ma}$, were also obtained from a rock of the Registro domain affected by the Itariri Shear Zone. In the Paleocene, a predominantly extensional tectonics occurred in the Serra do Mar region, leading to the Continental Rift System of southeastern Brazil (Almeida 1976; Riccomini et al. 1989; Zalán and Oliveira 2005), accelerating the exhumation and denudation processes. This period is recorded in the Areado Granite of the Mongaguá domain.

The available data attest that cooling of the Registro and Mongaguá terranes changed from the $110^{\circ} \mathrm{C}$ isotherm to the $60^{\circ} \mathrm{C}$ isotherm at different time periods. The similarity of the values obtained from a sample of the Registro domain and the value obtained for the Cubatão Shear Zone mylonite suggests that around 120 Ma this shear zone was reactivated with important vertical component.

\section{Dom Feliciano Belt}

The Dom Feliciano Belt (DFB) represents the major geotectonic unit in the southern part of the Mantiqueira Province (Almeida et al. 1981; Silva et al. 2005a), crop out roughly $\mathrm{N}-\mathrm{S}$, and occupies the entire eastern segment of southern Brazil and Uruguay (Fig. 1). Its evolution is associated with the transpressional tectonics related to the Neoproterozoic and Early Paleozoic West Gondwana collage. The Dom Feliciano Belt consists of supracrustal rocks and granitic batholiths with contacts defined by high-angle ductile NE-SW shear zones. Remnants of Paleoproterozoic basement inliers can be found on the eastern border (Basei et al. 2000).

Tectonic compartmentation

From its southern outcrops in Uruguay to its termination in Santa Catarina in Brazil, the DFB is composed of three crustal sectors separated by tectonic contacts (Fig. 1). They are (a) the Granite Belt (Florianópolis and Pelotas Batholiths in Brazil and the Aiguá Batholith in Uruguay), composed of deformed I-type medium to high-K calcalkaline granites and alkaline granitoid rocks; (b) the Schist Belt (Brusque and Porongos Metamorphic Complexes in Brazil and the Lavalleja Group in Uruguay), constituted by volcano-sedimentary rocks metamorphosed in greenschist to amphibolite facies with associated granitoids; and (c) the foreland basin deposits (Itajaí and Camaquã Basins in Brazil and the Arroyo del Soldado and Piriápolis Basins in Uruguay), composed of anchimetamorphic sedimentary and volcanic rocks, situated between the Schist belt and the Archean-Paleoproterozoic foreland to the West.

The Major Gercino Shear Zone (MGSZ) defined by Trainini et al. (1978) in Santa Catarina state (Fig. 9a) is part of a lithospheric-scale discontinuity in the DFB and is a prominent feature of the Proterozoic terranes in southern Brazil and Uruguay (Hallinan et al. 1993; Basei et al. 2000, 2008). This major lithospheric-scale suture, denominated by Basei et al. (2005) as the Sierra Ballena-Major Gercino Lineament (SBMGL), forms a $\sim 1,400 \mathrm{~km}$-long shear system and is marked by strong linear negative gravity anomalies (Mantovani et al. 1989; Hallinan et al. 1993). The SBMGL is a crustal discontinuity that encompasses several anastomosed shear zones, striking NNE and NE with dominant transcurrent kinematics, which controlled the intrusion of calc-alkaline granites, and in which syn-tectonic calc-alkaline, peraluminous and alkaline granites occurred (Picada 1971; Bitencourt and Nardi 2000, 2004; Oyhantçabal et al. 2007, 2009a).

The DFB schist belt is represented by the Brusque Metamorphic Complex in Santa Catarina (Basei 1985; Silva 1991; Philipp et al. 2004). It is composed of metavolcano-sedimentary rocks which underwent polyphase deformation resulting in NW-verging nappes formed during the main metamorphic episode in the Neoproterozoic which reached upper greenschist - lower amphibolite facies (Basei et al. 2000). The Schist Belt was intruded by late-tectonic granites: the two mica leucogranites of the São João Batista suite, the porphyritic biotite granites of the Valsungana suite, and the biotite granites of the Nova Trento suite. Similar features are also documented in other parts of the Schist Belt in Rio Grande do Sul, Porongos Metamorphic Complex, and Uruguay, Lavalleja Metamorphic Complex (Basei et al. 2006). The Granite Belt is represented by the Florianópolis Batholith (Fig. 1) composed of three main suites. The deformed tonalites to granodiorites and migmatites of Águas Mornas Suite is the oldest one, the quartz-diorites to quartz-monzonites of São Pedro de Alcântara Suite and the late alkaline leucogranites of Pedras Grandes Suite. The U-Pb ages are in the 640595 Ma time interval. The Pelotas Batholith in RS state (Fig. 1) comprises the Pinheiro Machado, Erval, Viamão, Encruzilhada do Sul, Cordilheira and Dom Feliciano granitic suites. The suites comprise high-K calc-alkaline to 


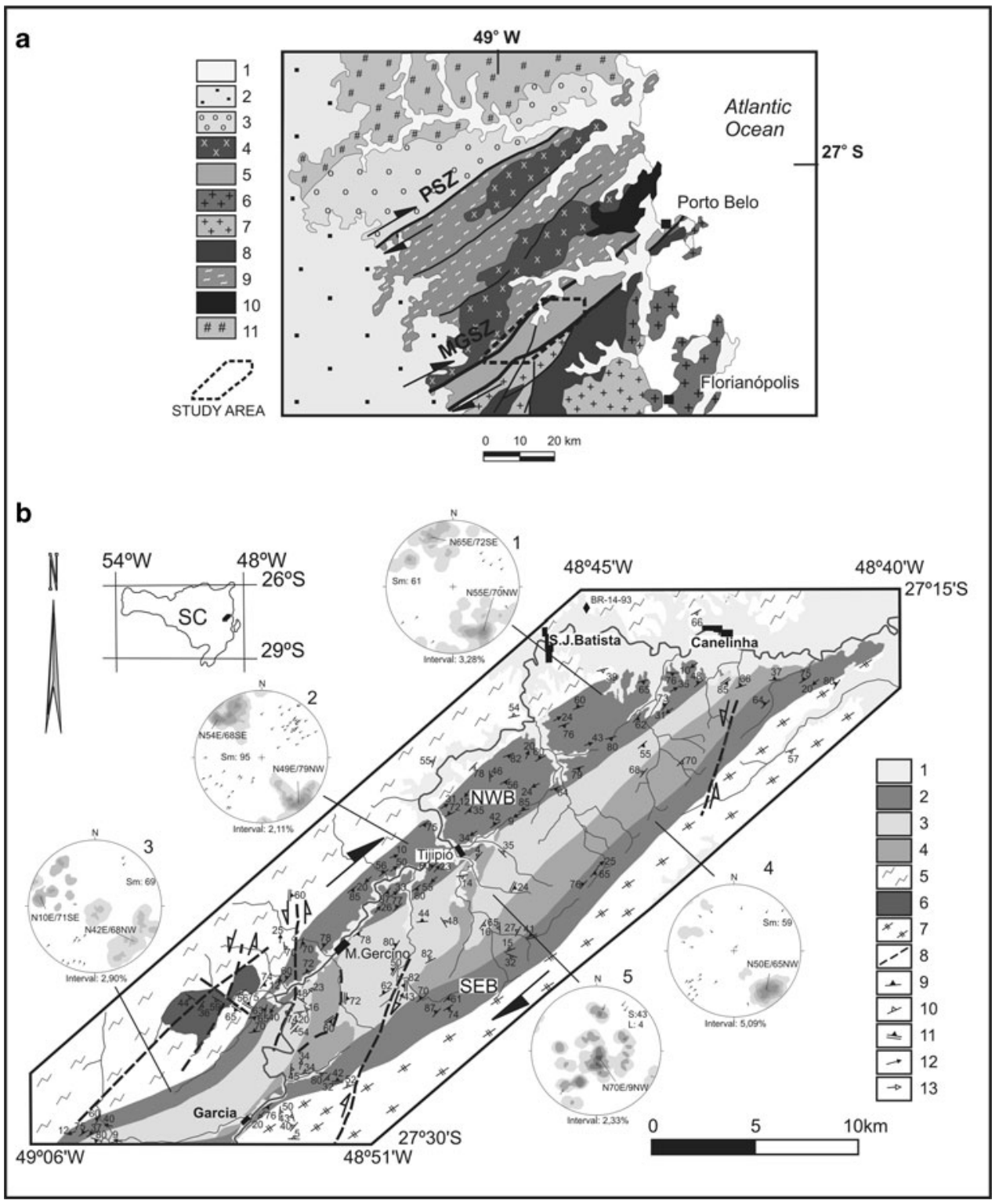

Fig. 9 a The southern portion of Dom Feliciano Belt, Santa Catarina, Brazil. 1 Cenozoic deposits; 2 Paleozoic to Mesozoic sediments of Paraná Basin; 3 Late Neoproterozoic-Early Paleozoic Itajaí volcanosedimentary basin; 4 Neoproterozoic intrusive granites; 5 Central Granitoids (Major Gercino Shear Zone); Neoproterozoic granitoid belt (Florianópolis Batholith): 6 Pedras Grandes Suite, 7 São Pedro de Alcântara Suite, 8 Águas Mornas Complex; 9 Neoproterozoic volcanosedimentary units of Brusque Complex; 10 Neoproterozoic gneisses and intrusive granites of Camboriú Complex; 11 Archean/ Paleoproterozoic Santa Catarina Granulitic Complex. PXZ Perimbó Shear Zone; MGSZ Major Gercino shear zone; A Amazonas craton;

alkaline compositions, with $\mathrm{U}-\mathrm{Pb}$ ages between 630 and 590 Ma (Philipp and Machado 2005).

Similarly to the southern Brazilian portion, in the Uruguayan Shield, the region east of the Schist Belt (Lavallela Group) is constituted by a domain of granitoid rocks (Bossi et al. 1988; Babinski et al. 1997; Basei et al.
$R P$ Rio de la Plata craton; $S F$ São Francisco craton; $K$ Kalahari craton; $C$ Congo craton; $D F B$ Dom Feliciano belt; b Geological map of Major Gercino shear zone (MGSZ). (1) Cenozoic deposits; MGSZ (2) Northwestern mylonite belt (NWB), Southeastern mylonite belt (SEB); Central Granitoids: (3) Fernandes granitoid association; (4) Rolador granitoid association; Terrains north of MGSZ: (5) Brusque metamorphic complex; (6) Intrusive granitoids; Terrains south of MGSZ: (7) Granite-migmatitic complex (Camboriú complex); (8) principal faults; (9) mylonitic foliation; (10) main foliation; (11) cataclastic foliation; (12) mineral lineation; (13) magmatic lineation

2000) where igneous rocks of different compositions predominate with poly-intrusive calc-alkaline granitoids, subordinately occurring isotropic granitoid bodies of syenogranitic composition. This domain constitutes the Aiguá Batholith, interpreted as the root of a Neoproterozoic magmatic arc. The Aiguá Batholith (A) has been correlated 
with the Pelotas and Florianópolis Batholiths further to the northeast. The oldest value observed in the Aiguá granitoids is a $\mathrm{Pb}-\mathrm{Pb}$ age on titanite of $614 \pm 3 \mathrm{Ma}$ (Oyhantçabal et al. 2007, 2009a, b). Late-tectonic granitic bodies within the Aigua Batholith yielded slightly younger U-Pb zircon ages between 590 and $570 \mathrm{Ma}$ (Preciozzi et al. 1999, 2001).

\section{The Major Gercino Shear Zone}

The MGSZ is a N-NE/S-SW-oriented shear zone that affects the Dom Feliciano Belt as an important suture separating the magmatic arc granites to the East (Granite Belt) and a folded supracrustal belt to the West (Schist Belt). These belts show different model NdTDM ages of 1,290 to $1,690 \mathrm{Ma}$ in the Granite Belt, and around 2,000 Ma in the Schist Belt (Mantovani et al. 1989; Basei 1990). The belts had independent origins and evolutions and achieved their present configuration around $540 \mathrm{Ma}$, when they were transported northwestwards to the border of the Rio de La Plata Craton which today underlies the Paraná basin (Basei et al. 2000). The syn-tectonic magmatism and the mylonites developed mainly during dextral lateral and oblique movement under compression led to the Granite Belt uplift.

The MGSZ presents a northwestern mylonite belt (NWB) 1 to $3.8 \mathrm{~km}$ wide and a $500 \mathrm{~m}$ to $2 \mathrm{~km}$ wide southeastern mylonite belt (SEB) (Fig. 9b), both striking $\mathrm{NE}$ and composed of protomylonites to ultramylonites with mainly dextral kinematics (Passarelli et al. 2010). The mylonitic belts form the limits of two petrographically, geochemically and isotopically different granitoid associations, usually referred to as the Central Granitoids: the Rolador Granitoid Association (RGA) and the Fernandes Granitoid Association (FGA).

A gradation from protomylonite to ultramylonites and phyllonite, passing through mylonite, characterizes the shear-related rocks of these two belts. The dip of NWB mylonitic foliation is mainly sub-vertical and shows a systematic strike variation: in the NE sector (Diagram 1, Fig. 9b) strikes N65E preferentially, N54E in the middle (Diagram 2, Fig. 9b), and then strikes N10E in the SW part (Diagram 3, Fig. 9b). The lineation exhibits dip directions of N55E with shallow plunges in the NE sector, N45E and S57W trends in the middle with intermediate to steep plunges, and plunge at intermediate to steep angles toward S20W in the SW sector.

The strike of the main mylonitic foliation of the SEB is preferentially N50E, with high-angle, NW dip (Diagram 4, Fig. 9b). The stretching lineation is defined by quartz ribbons and elongated feldspar porphyroclasts and by the alignment of biotite and muscovite flakes. The lineation dips S50W, with intermediate to low plunge (max. 20).
The variations of stretching lineation plunge in the MGSZ may reflect along-strike variations in finite strain or strain partitioning, revealing, in a no continuous manner, the record of a progressive transition from early stages of thrust to transpressional tectonics (Passarelli et al. 2010).

The mylonites of MGSZ derived mainly from granitoids which undergone dominant processes of grain-size reduction by dynamic re-crystallization of quartz, fracturing of plagioclase and K-feldspar during deformation. The mylonitization in greenschist facies conditions promoted the neoformation of sericite, chlorite, biotite, albite, clinozoisite/zoisite and epidote. The granitoid bodies that occur between the NWB and the SEB are elongated (Fig. 9b), and their borders are sheared, but they are usually only weakly deformed or megascopically isotropic in the cores. The presence of a range between magmatic and hightemperature solid-state microstructures where additionally sub-magmatic microstructures were characterized and the apparent rotation of the magmatic structures into the direction of the mylonitic belts indicate that during and after crystallization of the plutons, the shear zone controlled the ascent and emplacement of magma in a dextral transpressional tectonic regime (Passarelli et al. 2010).

The flat-lying magmatic/submagmatic and high-temperature solid-state microstructures (Diagram 5, Fig. 9), e.g., chessboard subgrain patterns in quartz, bent plagioclases and kinked biotites (see Fig. 11; Passarelli et al. 2010) is possibly a record of an early control of the intrusion by the initial stages of an oblique/thrust shear zone, which placed the Granite Belt over the Schist Belt. The shear zone evolved to a transpressive one only during the later stages after the peak of dynamic metamorphism, as observed in several shear zones of the southern Brazil and Uruguay. In addition, flat-lying low-temperature deformation microstructures are locally preserved on the SW sector of the NWB (Diagram 3, Fig. 9).

Correlations between the major southern Brazilian and Uruguayan shear zones have already been discussed by a number of authors (Basei 1990; Passarelli et al. 1993; Fernandes and Koester 1999; Basei et al. 2000; Bitencourt and Nardi 2000; Bossi and Gaucher 2004; Oyhantçabal et al. 2009a; Passarelli et al. 2010) based on the strong suggestion of geometrical and geophysical continuities (Mantovani et al. 1989). Together with the Cordilheira (RS) and Sierra Ballena (UY) Shear Zones, the MGSZ is considered part of a lithospheric-scale system of discontinuities that separates geochemical and isotopically distinct terranes (Basei et al. 2008). It is important to stress out that the Cordilheira Shear Zone is in the literature referred as Dorsal do Canguçu Shear Zone (e.g. Frantz et al. 2003; Philipp and Machado 2005). This interpretation is not accepted here and considered instead as two distinct and independent shear zones, parallel to one another. The Cordilheira, as 
mentioned before, belongs to the suture that separates two distinct terranes (Basei et al. 2000; Passarelli et al. 2006), whereas Dorsal do Canguçu is a shear zone that occurs inside the Pelotas Batolith (Fig. 1), as characterized by Jost et al. (1984) and Sadowski and Motidome (1987).

The N65W-trending principal compressional stress in the MGSZ in Santa Catarina (Passarelli et al. 1993, 1997) guaranteed a significant component of pure shear deformation as also observed in the transpressional sinistral phase of the SBSZ in Uruguay (Oyhantçabal et al. 2009a, b) and in the Cordilheira Shear Zone in RS (Basei et al. 2008) during a single episode.

Ages of main deformation and cooling episodes

The evolution of the DFB is related with both a tangential tectonic regime and a transcurrent one in the Neoproterozoic terranes of southern Brazil (Frantz and Botelho 2000). The first one is related to continent-continent collision (Basei and Hawkesworth 1993; Nardi and Frantz 1995; Basei et al. 2000; Philipp and Machado 2005). The tangential regime, defined by low-angle planar structures, could represent the timing of continental collision and is identified in Rio Grande do Sul under amphibolite facies metamorphic conditions (Fernandes et al. 1992) and in the MGSZ in Santa Catarina (Bitencourt and Nardi 1993; Passarelli et al. 2010). After peak metamorphic conditions were reached, N-S sinistral and NE dextral transcurrent shearing began (Basei 1990; Fernandes et al. 1992; Bitencourt and Nardi 1993), under low-grade metamorphic conditions.

Preciozzi et al. (1993) outlined the evolution for the Dom Feliciano Belt in Uruguay characterized by four major events. The first one would be represented by low- to high-grade metamorphism of the supracrustal Lavalleja Group responsible for the origin of orthogneisses and migmatites. Shear zones with associated granitoids of $c a$. $650 \mathrm{Ma}$ represent the second event. The third event is characterized by late-wrenching and post-orogenic granitoids with ages ranging from 630 to $550 \mathrm{Ma}$. This event also generated a highly strained zone involving imbricated units. Finally, the fourth event generated late thrust and post-wrenching granitoids.

In Santa Catarina, Major Gercino region, the transpressional phase of the MGSZ is constrained by the emplacement of the meta- to peraluminous calc-alkaline elongated granites of the Central Granitoids (FGA and RGA). The $\mathrm{U}-\mathrm{Pb}$ zircon ages for this syn-transpressional magmatism range from 610 to $615 \mathrm{Ma}$ and are interpreted as the interval of formation of both granitic associations (Passarelli et al. 2010).

In Porto Belo area, the early high-K, calc-alkaline granitic magmatism of $c a$. 650-630 Ma (Bitencourt and Nardi
2000) was mainly controlled by flat-lying shear zones. In the same period, in the Cordilheira Shear Zone (Rio Grande do Sul State), the emplacement of granitic intrusions from 658 to $625 \mathrm{Ma}$ (Frantz et al. 2003) was controlled by a transpressional deformation in a steep dipping shear zone. The period of 625-617 Ma represents a transition from a transpressional to a transtractive period. The emplacement of the late- and post-tectonic granite suites occurred later between 615 and $580 \mathrm{Ma}$, with a peak at approximately $600 \mathrm{Ma}$ (Babinski et al. 1997) defined by shoshonitic magmatism (Bitencourt and Nardi 2000). The transtensional period is characterized by the emplacement of granites with $\mathrm{U}-\mathrm{Pb}$ ages around $605 \mathrm{Ma}$ (Frantz et al. 2003) followed by younger alkaline magmatism.

Additionally, Philipp and Machado (2005) pointed out that the magmatism of the Pelotas Batholith corresponding to the age of tangential deformation supplied an interval of 630-610 Ma and rocks with ages between 570 and $600 \mathrm{Ma}$ may correspond to the development of high-angle ductile shear zones.

In the Aiguá Batholith, Uruguay, the $614 \pm 3$ Ma syntectonic intrusions associated with the SBSZ (Oyhantçabal et al. 2007) support a similar time interval for the transpressional episode observed in the MGSZ, in SC state. Two main transpressional episodes can be separated from an extensional one with an age of $c a .590 \mathrm{Ma}$ (Oyhantçabal et al. 2009a, b): (1) an early, associated with the nucleation of conjugate shear zones and (2) a late event, associated with sinistral reactivation of the NS-trending shear zones. The age of the second transpressional episode is constrained by the ${ }^{40} \mathrm{Ar} /{ }^{39} \mathrm{Ar}$ cooling age of muscovite from quartz mylonite (586 $\pm 2 \mathrm{Ma}$; Oyhantçabal et al. 2009a) similar to U-Pb ages ranging from 570 to $580 \mathrm{Ma}$ obtained for the alkaline felsic magmatism from Uruguay to southern Brazil (Siga et al. 1997; Leite et al. 1998; Hartmann et al. 2002; Chemale et al. 2003).

In Uruguay, U-Pb SHRIMP zircon ages of $564 \pm 7 \mathrm{Ma}$ (syntectonic Maldonado granite, Oyhantçabal et al., 2009b) and zircon $\mathrm{U}-\mathrm{Pb}$ age of $551 \pm 4 \mathrm{Ma}$ (sintectonic alkaline magmatism associated with mylonitic porphyries, Oyhantçabal et al. 2010 this volume) are interpreted to represent late movements along the SBSZ.

$\mathrm{K} / \mathrm{Ar}$ ages on biotites and muscovites of $\mathrm{ca} .570 \mathrm{Ma}$ from mylonites of MGSZ, northern belt (Fig. 9b) are indistinguishable from the K/Ar ages of the Central Granites and represent the time of cooling through the $300-350^{\circ} \mathrm{C}$ interval (McDougall and Harrison 1999) after the regional thermal peak. One muscovite sample from a mylonite in the southern belt is probably younger ( $\mathrm{ca}$. $540 \mathrm{Ma}$ ), suggesting that the movements along the two shear zones may have occurred at different times (Passarelli et al. 2010).

In the Rio Grande do Sul state, analogous biotite $\mathrm{K}-\mathrm{Ar}$ ages around $570 \mathrm{Ma}$ were obtained in syn-transcurrent 
granitoids of the Cordilheira Shear Zone (Koester et al. 1997) and mica Ar-Ar and biotite K-Ar dating on mylonites of ductile shear zones in the eastern Pelotas Batholith, ranging from 540 to $530 \mathrm{Ma}$, are interpreted as result of a reactivation of faults related to a late thermal-tectonic event probably responsible for the installation of the Camaquã Basin (Philipp and Machado 2005). K-Ar ages of ca. $530 \mathrm{Ma}$ obtained from biotite, which are similar to those obtained in the ZCMG, were also associated with ductile-brittle to brittle structures (open normal folds, normal and reverse faults and fractures) in Uruguay (Mallmann et al. 2004).

Additionally, ages around $570 \mathrm{Ma}$ can also be found in the late stages of the Florianópolis Batholith magmatism (Basei et al. 2000; Silva et al. 2005b). Similar Rb-Sr whole-rock ages are also found for parts of the Pelotas Batholith (Soliani 1986; Philipp and Machado 2005). Latetectonic granite bodies within the Aiguá Batholith (Uruguay) yielded $\mathrm{U}-\mathrm{Pb}$ zircon ages up to $570 \mathrm{Ma}$ (Preciozzi et al. 2001).

Shear zone reactivations in the southern portion of the Mantiqueira Province characterized in the Devonian (359 and $377 \mathrm{Ma}$ ) can be associated with an exhumation event related to block tectonics correlated the Paraná Basin evolution (Hackspacher and Tello Sáenz 2006; Passarelli et al. 2010), and in the Triassic (206 and $230 \mathrm{Ma}$ ) in mylonites of the northern branch of the Major Gercino Shear Zone, in this case probably associated with a thermal pulse connected to an early phase of the opening of the South Atlantic Ocean.

\section{Discussion}

As a consequence of the collision of crustal masses that led to the formation of Western Gondwana, in all south-eastern Brazilian and Uruguayan portions, major shear zones developed with lateral movements that accommodated most of the energy associated with the collisions. This scenario, built during the Ediacaran-Cambrian transition, is registered along the totality of the Mantiqueira Province as a result of the juxtaposition of the São Francisco, Kalahari, Paranapanema and Rio de La Plata cratons (Fig. 10).

The lateral escape tectonics combined with a vertical component was responsible for the juxtaposition of terranes from distinct structural levels. The oblique movement between most of the tectonic blocks determined the transpressional character of the main suture zones. During the late stages of the Western Gondwana formation, distensional structures were installed later to the principal compression (Fig. 11).

In the southeastern and central portions of the Ribeira Belt, structural features characteristic of the two types of

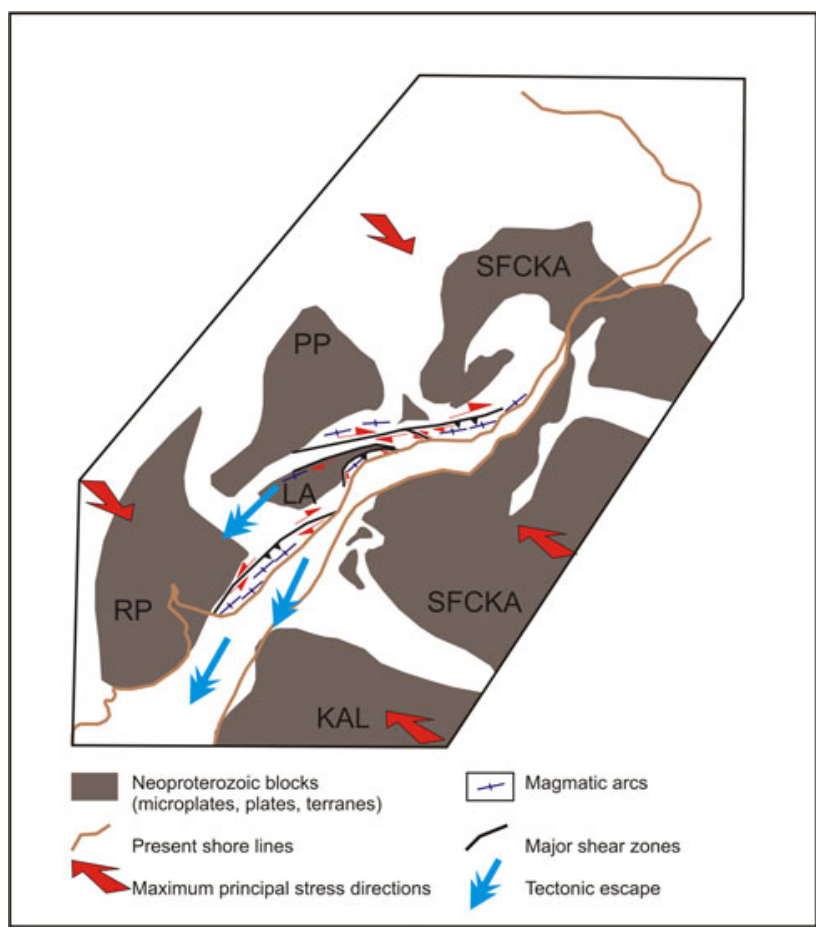

Fig. 10 Sketch diagram for the paleogeographic scenery of the closure of the Brasiliano-Panafrican Cycle, showing the main collisional segments (plates, microplates, terranes). Neoproterozoic blocks (plates, microplates, microcontinents, terranes): SFCKA São Francisco-Congo-Kasai-Angola, PP Paranapanema, KAL Kalahari, $R P$ Rio de La Plata, $L A$ Luis Alves. The maximum principal stress directions and tectonic escape are shown (Simplified and modified from Almeida et al. 2000)

deformation (Ebert and Hasui 1998) are recognized: transcurrency (non-coaxial deformation-directional structures of predominantly dextral and sinistral movement) and shortening perpendicular to the shear zones (coaxial deformation). This attests for that a large part of the Ribeira Belt underwent dextral transpression generated by oblique collision between different terranes in the $\mathrm{E}-\mathrm{W}$ direction, accommodated by means of the deformation partitioning in NW-SE-trending compressive and NE-SW-trending transcurrent structures along this belt (Fig. 11). The transpressional deformational character is also characterized in the Dom Feliciano Belt, mainly represented by the orogenparallel Major Gercino-Sierra Ballena Shear System (Fig. 11).

The partitioning of deformation, common in tectonic limits, has already been reported in the Mantiqueira Province (Ebert and Hasui 1998; Hackspacher and Godoy 1999; Egydio-Silva et al. 2005 and others) and it is caused mainly by collision of the irregular continental margins, besides for processes of oblique convergence. The most of the natural orogens accommodates transpressional deformation, with orogen-parallel tectonic transport in response to oblique convergence (Jezek et al. 2002). In the 


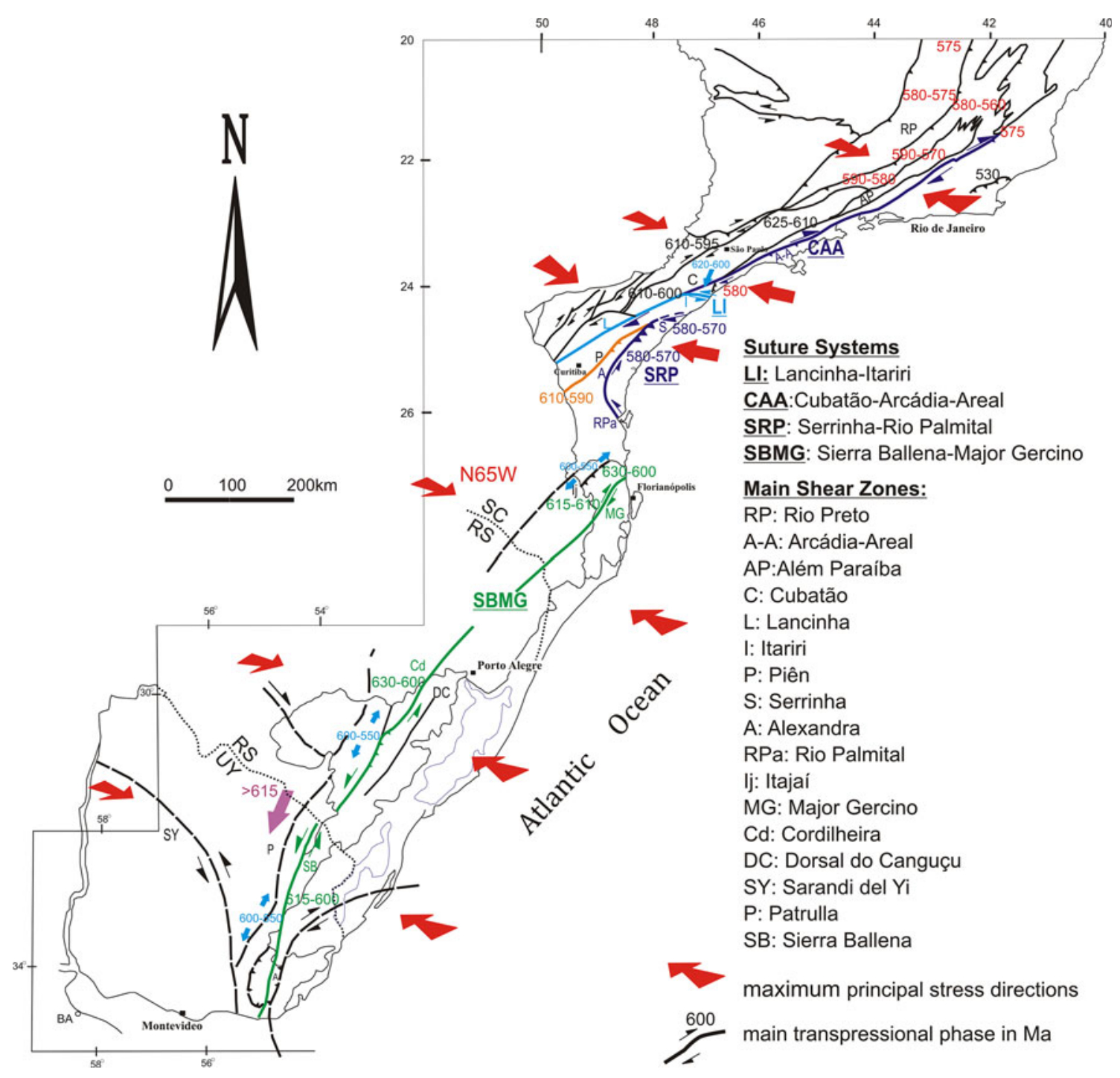

Fig. 11 General outline of the Mantiqueira Province (Brazil-Uruguay) showing the main shear zones with the main transpressional phase in Ma and the maximum compressional stress directions

transpressive shear zones (Harland 1971), the concept of strain partitioning is characterized into zones of simple shear deformation and domains of pure shear (Tikoff and Teyssier 1994).

In Fig. 11, the principal compression directions of the transpressional systems are represented (Egydio-Silva and Mainprice 1999; Hackspacher and Godoy 1999; Campanha and Brito Neves 2004; Faleiros and Campanha 2004; Hippertt et al. 2001; Oyhantçabal et al. 2009a, b, Passarelli et al. 2004b), as well as the ages of these processes. The syn-collisional and transpressional phase is older in the Dom Feliciano Belt when compared to that of the Ribeira Belt, confirming the diachronic character of the evolution of these orogenic belts, as brought into attention by several authors (Brito Neves and Cordani 1991; Brito Neves et al. 1999; Almeida et al. 2000).
In the Dom Feliciano Belt, the transpressional event in the Major Gercino - Sierra Ballena System occurred between approximately 630 and $600 \mathrm{Ma}$ (Babinski et al. 1996; Basei et al. 2000; Bitencourt and Nardi 2000; Philipp et al. 2003; Chemale et al. 2003; Oyhantçabal et al. 2009a, 2009b; Passarelli et al. 2010), with a reasonable concentration of syn-kinematic granitic activity at $c a .615 \mathrm{Ma}$. Older granitic magmatism ( $\mathrm{ca}$.650-630 Ma) controlled by low-angle shear zones is recorded locally in the Porto Belo region in Santa Catarina (Bitencourt and Nardi 2000; Chemale et al. 2003) and in the Quiteria Granite (Rio Grande do Sul), which could record the beginning of the transpressional phase (Frantz et al. 2003) of this shear system in Rio Grande do Sul. The N65W-trending principal compressional component led to dextral and sinistral movements in this shear system in association with a strong 
coaxial component. Therefore, the Sierra Ballena Shear Zone sinistral and the Major Gercino Shear Zone dextral movements were generated simultaneously, as a local response, as a function of the attitude of these lineaments in relation to the principal compressional stress. This process is repeated in several lineaments, mainly those of the south-Brazilian portion. In Uruguay (Sierra Ballena Shear Zone), as in the Itariri Shear Zone, a $c a$. N20E-trending compressional component is recorded associated with movements prior to the main transpressional phase (Oyhantçabal et al. 2009a, b).

In the Ribeira Belt, the transpressional deformation was not simultaneous in the major shear zones. In its northern and central portion, the interval between 590 and $560 \mathrm{Ma}$ is defined by $\mathrm{U}-\mathrm{Pb}$ dating of titanite and monazite for the WNW thrust and zircon $\mathrm{U}-\mathrm{Pb}$ dating of syn-kinematic granites (Heilbron et al. 1995; Machado et al. 1996; Heilbron and Machado 2003; Silva et al. 2003; Mendes et al. 2006; Vauchez et al. 2007), with high concentration between 580 and $570 \mathrm{Ma}$. This period is associated with the juxtaposition of the Andrelândia, Juiz de Fora and Paraíba do Sul terranes (Figs. 1, 11) to the SE border of the São Francisco Craton.

In the central-southern portion of the Ribeira Belt, north of the Cubatão-Arcádia-Areal suture zone, the transpressional phase defined mainly by the generation of compressive tectonic-associated granites occurred between $c a$. 625 and $595 \mathrm{Ma}$ (Ebert et al. 1996; Hackspacher and Godoy 1999; Hackspacher et al. 2004b; Passarelli et al. 2004a, 2008), with a conspicuous peak at ca. $610 \mathrm{Ma}$. This period is associated with the juxtaposition of the SocorroGuaxupé Nappe, the Apiaí and Embu Terranes and the Curitiba Microplate (Figs. 1, 11) to the eastern border of the Paranapanema Craton. A N20E-N40E principal compression was responsible for the sinistral movement of the Itariri Shear Zone during the juxtaposition of the Embu and Curitiba/Registro terranes (Passarelli et al. 2004b) in a period that must be better defined (between 620 and $600 \mathrm{Ma})$. The relationship between this compressional movement and the general compression between E-W and $\mathrm{N} 65 \mathrm{~W}$, observed in practically all the Ribeira Belt, needs to be further investigated. This previous NE compressional direction is recorded only in the Sierra Ballena Shear Zone in Uruguay (Oyhantçabal et al. 2009a, b). South of the Cubatão Shear Zone, the transpressional phase resulting from the collision between the Luis Alves and Curitiba microplates was probably concomitant with the period reported above, having as lower limit the age of the Piên magmatic arc and post-tectonic granites, between 610 and $590 \mathrm{Ma}$ (Harara et al. 1997; Basei et al. 2000).

The juxtaposition of the Coastal terrane to the other terranes was later, between 580 and 570 Ma (Heilbron et al. 1995; Machado et al. 1996, Pedrosa-Soares and
Wiedmann-Leonardos 2000; Passarelli 2001; Passarelli et al. 2004a, b, 2008) through the Cubatão-Arcádia-Areal Suture Zone in the northern portion and the Serrinha-Rio Palmital Suture Zone in the southern portion. This juxtaposition reactivated the Lancinha-Itariri suture, leading to a sinistral movement in the Itariri ramification $(\mathrm{E}-\mathrm{W})$ and a dextral movement in the Lancinha-Cubatão ramification (N60E). Along with this compressional movement, a tectonic wedge was formed, limited by the transcurrent to transpressional faulting, with micro-thrusting verging westwards inside the Mongaguá Terrane (Figs. 1, 11). The Serrinha-Rio Palmital Shear System in the northern portion developed through a frontal ramp varying to oblique and lateral ramps of dextral movement, under amphibolite facies metamorphic conditions (Passarelli et al. 2007). In its southern portion the Palmital and Alexandra, transcurrent shear zones are characterized by sinistral kinematics with oblique component marked by coexisting strike-slip and down-dip lineations (Cury et al. 2008).

Additionally, from the compilation of all geochronological data obtained by the $\mathrm{U}-\mathrm{Pb}, \mathrm{K}-\mathrm{Ar} / \mathrm{Ar}-\mathrm{Ar}$ methods applied to minerals and fine fractions and fission-track dating of apatites and respective closure temperatures, a slow cooling and uplift of the terranes is suggested by the biotite $\mathrm{K}-\mathrm{Ar}$ ages. The $\mathrm{K}-\mathrm{Ar}$ results for the fine fractions indicate latter brittle reactivation of the shear zones in Devonian times, possibly associated with the stabilization phase with low exhumation of tectonic blocks of the Mantiqueira Province, and in the Triassic times, reflecting the initial removal of heat from beneath Pangea and the beginning of fragmentation of Gondwana.

The diachronism regarding the Mantiqueira Province Shear Zones is associated with distinct pulses of approximation of the São Francisco-Congo, Kalahari and Rio de la Plata cratons and minor continental fragments that occurred along a period of $c a .60 \mathrm{Ma}$, from the initial collision phase until the lateral escape phase predominantly defined by the major transcurrent shear zones.

\section{Conclusions}

Continental collisions are processes closely related to the formation of supercontinents. The main mechanisms that accommodate crustal shortening are subduction, thrusting and folding, as well as lateral mass transport (Molnar and Tapponnier 1975; Tapponnier et al.1982; Peltzer and Tapponnier 1988; Aitchison and Davis 2004). Most part of the plate limits presents a markedly oblique relative velocity vector at the borders, and the accommodation of these oblique movements usually involves types of plateboundary related strike-slip faults with very characteristic kinematic roles in the convergent plate limits (Woodcock 
1986). In a continental collision process, the variation in the tectonic regime (thrust tectonics and transcurrent tectonics), as well as the sense of shear of the transcurrent/ transpressional zones, reflects the kinematics accommodation, where the perimeter and shape of the rigid blocks play an important role, as can be observed along the whole Mantiqueira Province.

The Ribeira and Dom Feliciano orogens, respectively, central and southern segments of the Mantiqueira Province, evolved during the formation of Western Gondwana in Neoproterozoic Brasiliano/Panafrican orogenic cycle. These old orogens resulted from the closing of the Adamastor Ocean caused by the convergence of cratons, microplates and minor terranes.

In the Ribeira and Dom Feliciano belts, the tectonic escape regime took place by means of extensive NEtrending ductile transpressive shear zones, juxtaposing different crustal levels parallel to the craton limits (Dantas et al. 2000; Hackspacher et al. 2004b).

In the central and southern Ribeira Belt, the escape tectonics took place at ca. $580 \mathrm{Ma}$ (Hackspacher and Godoy 1999; Silva et al. 2005a, b) where dextral orogenparallel wrench faulting dominated (Vauchez et al. 2007). These wrench faulting favoured the formation of NEtrending pull-apart basins (Jacobs and Thomas 2004) that were filled by continental sediments.

The escape-related shear zones are exposed for $c a$. $3,000 \mathrm{~km}$ along predominantly dextral transpressional zones in its northern portion and dextral and sinistral transpressional zones in its southern portion. The kinematics of the major shear zones detailed here, with concavity mainly toward ESE, led to simultaneous movements of opposite directions at their terminations (sinistral to the south and dextral to the north), resulting from collisions between microplates and cratons through a predominantly westward continuous compression. North of the Itariri Shear Zone there is regularity in the dextral movement of the shear zones.

Acknowledgments We thank FAPESP-Fundação de Amparo à Pesquisa do Estado de São Paulo (grants 03/13246-6; 04/07837-4; 05/ 58688-1) for financial support given to fieldwork, litogeochemical and isotopic analyses.

Open Access This article is distributed under the terms of the Creative Commons Attribution Noncommercial License which permits any noncommercial use, distribution, and reproduction in any medium, provided the original author(s) and source are credited.

\section{References}

Aitchison JC, Davis AM (2004) Evidence for the multiphase nature of the India-Asia collision from the Yarlung Tsangpo suture zone, Tibet. Geol Soc Lond Spec Publ 226:217-233
Almeida FFM (1976) The system of continental rifts bordering the Santos Basin, Brazil. An Acad Bras Ciênc 48:15-26

Almeida SHS, Ebert HD (2006) Estruturação tectônica e análise deformacional do segmento central do Cinturão Ribeira na Serra da Bocaina, nos estados de São Paulo e Rio de Janeiro. Rev Bras Geoc 36:269-281

Almeida FFM, Hasui Y (1984) O Pré-Cambriano do Brasil. Edgard Blucher, São Paulo

Almeida FFM, Hasui Y, Brito Neves BB, Fuck RA (1981) Brazilian structural provinces, an introduction. Earth Sci Rev 17:1-29

Almeida JCH, Tupinambá M, Heilbron M, Trouw R (1998) Geometric and kinematic analysis at the Central Tectonic Boundary of the Ribeira belt, Southeastern Brazil. In: Congr Bras Geol 39, SBG, Anais, p 32

Almeida FFM, Brito Neves BB, Carneiro CDR (2000) The origin and evolution of the South American Plataform. Earth Sci Rev 50:77-111

Amaral G, Born H, Hadler NJC, Iunes PJ, Kawashita K, Machado DL Jr, Oliveira EP, Paulo SR, Tello Saenz CA (1997) Fission track analysis of apatites from São Francisco craton and Mesozoic alcaline-carbonatite complexes from central and southeastern Brazil. J S Am Earth Sci 10:285-294

Babinski M, Chemale F Jr, Hartmann LA, Van Schmus WR, Silva LC (1996) Juvenile accretion at 750-700 Ma in southern Brazil. Geology 24:439-442

Babinski M, Chemale F Jr, Van Schmus WR, Hartmann LA, Silva LC (1997) U-Pb and Sm-Nd geochronology of the Neoproterozoic Granitic-Gneissic Dom Feliciano Belt, Southern Brazil. J S Am Earth Sci 10:263-274

Basei MAS (1985) O Cinturão Dom Feliciano em Santa Catarina. PhD Thesis, University of São Paulo

Basei MAS (1990) The Major Gercino-Dorsal do Canguçu Shear Zone. In: Colloq Afr Geol 15. Nancy, France. Abstracts, pp 166

Basei MAS, Hawkesworth C (1993) O Magmatismo do Cinturão Dom Feliciano (SC) e sua importância no estabelecimento das principais descontinuidades crustais da região sul-brasileira. In: Simp Int Neoprot-Cambrico Cuenca del Plata, 1, La PalomaMinas. Res Ext 2, n. 41

Basei MAS, Siga O Jr, Machiavelli A, Mancini F (1992) Evolução tectônica dos terrenos entre os Cinturões Ribeira e Dom Feliciano (PR-SC). Rev Bras Geoc 22:216-221

Basei MAS, Siga O Jr, Masquelin H, Harara OMM, Reis Neto JM, Preciozzi F (2000) The Dom Feliciano Belt of Brazil and Uruguay and its Foreland Domain the Rio de la Plata Craton: framework, tectonic evolution and correlation with similar provinces of Southwestern Africa. In: Cordani UG, Milani EJ, Thomaz Filho A, Campos DA (eds) Tectonic evolution of South America, Rio de Janeiro, pp 311-334

Basei MAS, Siga O Jr, Kaulfuss GA, Cordeiro H, Nutman AP, Sato K, Cury LF, Prazeres Filho HJ, Passarelli CR, Harara OMM (2003) Geochronology and isotope geology of votuverava and Perau Mesoproterozoic Basins, Southern Ribeira belt, Brazil. In: S Am Symp Isot Geol 4, Salvador, Short Paper, vol 2, pp 501-504

Basei MAS, Frimmel HE, Nutman AP, Preciozzi F, Jacob J (2005) A connection between the Neoproterozoic Dom Feliciano (Brazil/ Uruguay) and Gariep (Namibia/South Africa) orogenic beltsevidence from a reconnaissance provenance study. Prec Res 139:195-221

Basei MAS, Frimmel HE, Nutman AP, Preciozzi F (2006) Provenance and depositional age of the Dom Feliciano Belt supracrustals units, Brazil-Uruguay: correlations with SW Africa. In: S Am Symp Isot Geol 5 Punta del Este, 2006. Short Papers, pp 45-48

Basei MAS, Frimmel HE, Nutman AP, Preciozzi F (2008) West Gondwana amalgamation based on detrital zircon ages from 
Neoproterozoic Ribeira and Dom Feliciano belts of South America and comparison with coeval sequences from SW Africa. Geol Soc Lond Spec Publ 294:239-256

Bitencourt MF, Nardi LSV (1993) Late to post-collisional Brasiliano magmatism in southernmost Brazil. An Acad Bras Ciênc 65:3-16

Bitencourt MF, Nardi LSV (2000) Tectonic Setting and sources of magmatism related to the southern Brazilian shear belt. Rev Bras Geoc 30:186-189

Bitencourt MF, Nardi LSV (2004) The role of xenoliths and flow segregation in the genesis and evolution of the Paleoproterozoic Itapema Granite, a crustally derived magma of shoshonitic affinity from southern Brazil. Lithos 73:1-19

Bossi J, Gaucher C (2004) The Cuchilla Dionisio Terrane, Uruguay: an allochthonous block accreted in the Cambrian to SWGondwana. Gond Res 7:661-674

Bossi J, Ferrando L, Montana J, Campal N, Morales H, Gancio F, Schipilov A, Pineyro D, Sprechmann P (1998) Carta geologica del Uruguay, escala 1:500, 000. Geoeditores, Montevideo

Boullier AM, Bouchez JL (1978) Le quartz en rubans dans les mylonites. Bull Soc Geol France 7:253-262

Brito Neves BB, Cordani UG (1991) Tectonic evolution of South America during the Late Proterozoic. Prec Res 53:23-40

Brito Neves BB, Sá JM, Nilson AA, Botelho NF (1995) A tafrogênese Estateriana nos blocos Paleoproterozóicos da América do Sul e processos subseqüentes. Geon 3:1-21

Brito Neves BB, Campos Neto MC, Fuck AR (1999) From Rodinia to Western Gonwana: an approach to the Brasiliano-Pan African Cycle and orogenic collage. Episodes 22:155-166

Brückl E, Bleibinhaus F, Gosar A, Grad M, Guterch A, Hrubcova P, Keller GR, Majdanski M, Sumanovac F, Tiira T, Yliniemi J, Hegedüs E, Thybo H (2007) Crustal structure due to collisional and escape tectonics in the Eastern Alps region based on profiles Alp01 and Alp02 from the ALP 2002 seismic experiment. J Geophys Res 112:B06308.1-B06308.25

Burke K, Sengor C (1986) Tectonic escape in the evolution of the continental crust. In: Barazangi M, Brown L (eds) Reflection seismology: the Continental Crust, geodynamics series, 14, pp 41-53

Campanha GAC, Brito Neves BB (2004) Frontal and oblique tectonics in the Brazilian Shield. Episodes 27:255-259

Campanha GAC, Sadowski GR (1999) Tectonics of the Southern Portion of the Ribeira Belt (Apiaí Domain). Prec Res 28:31-51

Campanha GAC, Faleiros FM, McReath I, Frascá H (2004) Neoproterozoic terrane collage and geochemistry signatures in the Southern Ribeira Belt. In: Int Geol Cong 32, 2004, Florence, Italy. Abstracts IUGS, 2004. CD-ROM

Campanha GAC, Basei MAS, Tassinari CCG, Nutman AP, Faleiros FM (2008) Constraining the age of Iporanga Formation with SHRIMP U-Pb zircon: implications for possible Ediacaran glaciation in the Ribeira Belt, SE Brazil. Gond Res 13:117-125

Campos Neto MC, Caby R (2000) Terrane accretion and upward extrusion of high-pressure granulites in the neoproterozoic nappes of Southeast Brazil: petrologic and structural constraints. Tecton 19:669-687

Campos Neto MC, Figueiredo MCH (1995) The Rio Doce Orogeny, southeastern Brazil. J S Am Earth Sci 8:143-162

Chemale F Jr, Mallmann G, Bitencourt MF, Kawashita K (2003) Isotope geology of syntectonic magmatism along the Major Gercino Shear Zone, southern Brazil: implications for the timing of deformation events. In: S Am Symp Isot Geol 4, Salvador. Short Papers, 2, pp 516-519

Cordani UG, Sato K (1999) Crustal evolution of the South American Platform, based on Nd isotopic systematics on granitoid rocks. Episodes 22:167-173
Cordani UG, Sato K, Teixeira W, Tassinari, CCG, Basei MAS (2000) Crustal evolution of the South American Platform. In: Cordani UG, Milani EJ, Thomaz Filho A, Campos DA (eds) Tectonic evolution of South America. Rio de Janeiro, pp 19-40

Cordani UG, Coutinho JMV, Nutman AP (2002) Geochronological constraints on the evolution of the Embu Complex, São Paulo, Brazil. J S Am Earth Sci 14:903-910

Cunningham WD, Alkmin FF, Marshak S (1998) A structural transect across the coastal mobile belt in the Brazilian highlands (latitude $20^{\circ} \mathrm{S}$ ): the roots of a Precambrian transpressional orogen. Prec Res 92:251-275

Cury LF, Kaulfuss GA, Siga O Jr, Basei MAS, Harara OMM, Sato K (2002) Idades U-Pb (zircões) de $1.75 \mathrm{Ga}$ em granitóides alcalinos deformados dos núcleos Betara e Tigre: evidências de regimes extensionais do Estateriano na faixa Apiaí. Geol USP Sér Cient 2:95-108

Cury LF, Siga O Jr, Sato K, Harara OMM, Basei MAS, Salazar Mora CA (2008) Shrimp zircon age of Rio do Poço Granitic Suite in the geochronological setting of Paranaguá Domain-Southern Brazil. In: S Am Symp Isot Geol, 6, San Carlos de Bariloche, 2008. Proceedings (CD-ROM)

Dantas ASL, Gimenez Filho A, Teixeira AL, Nagata N, Fernandes LA, Albuquerque Filho JL, Frascá MHBO (1987a) Geologia das folhas Juquiá (SC.23-V-A-I-4) e Miracatu (SG23-V-A-II-3), Estado de São Paulo. IPT, São Paulo

Dantas ASL, Gimenez Filho A, Teixeira AL, Nagata N, Fernandes LA, Albuquerque Filho JL, Frascá MHBO (1987b) Evolução geológica e estrutural da faixa costeira nas regiões de Juquiá e Miracatu, Sul do Estado de São Paulo. In: Simp Reg Geol, 6, Rio Claro. Anais1, pp 173-189

Dantas EL, Hackspacher PC, Fetter AH, Sato K, Pimentel MM, Godoy AM (2000) Nd Isotope systematics related to Proterozoic evolution of the Central Ribeira Belt in the state of São Paulo, SE Brazil. Rev Bras Geoc 30:140-143

Dias Neto CM, Tassinari CCG, Munhá J (2002) Evolução Tectonotermal do Complexo Costeiro (Faixa de Dobramentos Ribeira) em São Paulo. In: Cong Bras Geol 41, João Pessoa. Anais, p 305

Ebert HD, Hasui Y (1998) Transpressional tectonics and strain partitioning during oblique collision between three plates in the Precambrian of southeast Brazil. In: Holdsworth RE, Strachan RA, Dewey JF (eds) Continental Transpressional and Transtensional Tectonic. Geol Soc, London, Spec Public 135, pp 231252

Ebert HD, Hasui Y, Sena Costa JB (1991) O caráter transpressivo do Cinturão Transcorrente Rio Paraíba do Sul. In Simp Nac Est Tect 3. Anais1, pp 139-141

Ebert HD, Chemale F Jr, Babinski M, Artur AC, Van Schmus WR (1996) Tectonic setting and U-Pb zircon dating of the plutonic Socorro Complex in the transpressive Rio Paraíba do Sul shear belt, SE Brazil. Tecton 15:688-699

Egydio-Silva M (1981) Análise estrutural das faixas ectiníticas associadas ao falhamento de Cubatão entre as regiões de Juquiá e Pedro Barros-Estado de São Paulo. Dissertation, University of São Paulo

Egydio-Silva M, Mainprice D (1999) Determination of stress directions from plagioclase fabrics in hig grade deformed rocks (Além Paraíba shear zone, Ribeira fold belt, southeastern Brazil). J Struct Geol 21:1751-1771

Egydio-Silva M, Vauchez A, Bascou J, Hippert J (2002) Hightemperature deformation in the neoproterozoic transpressional Ribeira Belt, southeast Brazil. Tectonophy 352:203-224

Egydio-Silva M, Vauchez A, Raposo MIB, Bascou J, Uhlein A (2005) Deformation regime variations in an arcuate transpressional orogen (Ribeira belt, SE Brazil) imaged by anisotropy of magnetic susceptibility in granulites. J Struct Geol 27:17501764 
Faleiros FM, Campanha GAC (2004) Petrografia e microestruturas de tectonitos da Zona de Cisalhamento Ribeira, Vale do Ribeira, SP e PR: implicações no zoneamento metamórfico e estrutural do Supergrupo Açungui e unidades correlatas. Rev Bras Geoc 34:419-430

Fassbinder E, Sadowski GR, Fiori AP (1994) Modelo de Riedel aplicado ao Lineamento da Lancinha, no Estado do Paraná. Bol Paran Geoc 42:173-184

Fernandes LAD, Koester E (1999) The Neoproterozoic Dorsal de Canguçu strike-slip shear zone: its nature and role in the tectonic evolution of southern Brazil. J Afr Earth Sci 29:3-24

Fernandes LAD, Tommasi A, Porcher CC (1992) Deformation patterns in the southern Brazilian branch of the Dom Feliciano Belt: a reappraisal. J South Am Earth Sci 5:77-96

Fiori AP (1985a) A Falha da Lancinha no Pré-Cambriano Paranaense: Reflexo de uma Falha Profunda? Bol Paran Geoc 36:03-14

Fiori AP (1985b) As Falhas Lancinha e de Morro Agudo e estruturas secundárias associadas. In: Simp Sul-Bras Geol 2, Florianópolis. Anais. SBG, pp 159-171

Fragoso-Cesar ARS (1980) O Cráton do Rio de La Plata e o Cinturão Dom Feliciano no Escudo Uruguaio-Sul-Riograndense. Cong Bras Geol 31, Camboriú, vol 5, pp 2879-2892

Frantz JC, Botelho NF (2000) Neoproterozoic granitic magmatism and evolution of the eastern dom feliciano belt in Southernmost Brazil: a tectonic model. Gond Res 3:7-19

Frantz JC, McNaughton NJ, Marques JC, Hartmann LA, Botelho NF, Caravaca G (2003) Shrimp U-Pb zircon ages of granitoids from southernmost Brazil: constraints on the temporal evolution on the Dorsal do Canguçu transcurrent shear zone and the eastern Dom Feliciano Belt. S Am Symp Isot Geol 4, Salvador. Short Papers 1, pp 174-177

Gallagher K, Hawkesworth CJ, Mantovani MSM (1995) Denudation, fission track analysis and the long-term evolution of passive margin topography: application to the southeast Brazilian margin. J S Am Earth Sci 8:65-77

Gimenez Filho A, Albuquerque Filho JL, Dantas ASL, Fernandes LA, Nagata N, Teixeira AL (1987) Geologia da Folha Miracatu, sulsudeste do estado de São Paulo. In: Simp Reg Geol, 6. Rio Claro, vol 1, pp 225-241

Gimenez Filho AG, Janasi VA, Campanha GAC, Teixeira W, Trevizoli LE Jr (2000) U-Pb dating and Rb-Sr isotope geochemistry of the Eastern portion of the Três Córregos Batolith Ribeira Fold Belt, São Paulo, Brazil. Rev Bras Geoc 30:45-50

Godoy DF, Hackspacher PC, Guedes S, Hadler Neto JC (2006) Reconhecimento da tectônica Mesozóica-Cenozóica na borda leste da Bacia do Paraná através da aplicação de traços de fissão em apatitas no Domo de Pitanga (Sudoeste de Rio Claro, SP). Geoc 25:151-164

Hackspacher PC, Godoy AM (1999) Vertical displacement during late-collisional escape tectonics (Brasiliano Orogeny) in the Ribeira Belt, São Paulo State, Brazil. J Afric Earth Sci 29:25-32

Hackspacher PC, Tello Sáenz CA (2006) Thermal history at the Mantiqueira Province, southeastern Brasil: modeling with fission track on zircon. In: S Am Symp Isot Geol 5, Punta del Este. Short Papers, pp 218-220

Hackspacher PC, Hadler Neto JC, Iunes PJ, Paulo SR, Ribeiro LFB, Tello Sáenz CA (1999) Alguns dados sobre o Período Cretáceo na Serra da Mantiqueira através de análise de traços de fissão em apatitas (ATFA). In: Simp sobre o Cretáceo do Brasil, 5, Serra Negra. Bol, pp 33-37

Hackspacher PC, Dantas EL, Spoladore A, Fetter AH, Oliveira MAF (2000) Evidence of Neoproterozoic Backarc Basin development in the Central Ribeira Belt, Southeastern Brazil: new geochronological and geochemical constraints from the São RoqueAçungui Groups. Rev Bras Geoc 30:110-114
Hackspacher PC, Ribeiro LFB, Ribeiro MCS, Fetter AH, Hadler Neto JC, Tello Sáenz CA, Dantas EL (2004a) Consolidation and break-up of the South American Platform in Southeastern Brazil: tectonothermal and denudation histories. Gond Res 7:91-101

Hackspacher PC, Fetter A, Teixeira W, Dantas E, Ebert H, Trouw R, Vasconcelos P (2004b) Final stages of the Brasiliano Orogenesis in SE Brazil: $\mathrm{U}-\mathrm{Pb}$ and ${ }^{40} \mathrm{Ar} /{ }^{39} \mathrm{Ar}$ evidence for overprinting of the Brasília Belt by the Ribeira Belt Tectonics. In: Weinberg R, Trouw R, Fuck R, Hackspacher PC (eds) The 750-550 Ma Brasiliano Event of South America. http://virtualexplorer.com.au/ article/2004/108/final-stages-of-the-brasiliano-orogeny

Hackspacher PC, Hadler Neto JC, Saad AR, Godoy DF, Ribeiro MCS, Ribeiro LFB, Franco AOB, Doranti C, Tello Sáenz CA, Iunes PJ, Guedes S (2008) Tectonic reactivation of the southamerican Platform, southeastern Brazil, during the Cretaceous time. In: Thermochron Workshop, 2008, Gramado, vol 1, pp 15-22

Hallinan SE, Mantovani MSM, Shukowsky W, Braggion I Jr (1993) Estrutura do Escudo Sul - Brasileiro: Uma revisão através de dados gravimétricos e magnetométricos. Rev Bras Geoc 23:201-214

Harara OMM, Basei MAS, Siga O Jr (1997) Geochronological and geochemical data on the transition zone between Luis Alves and Atuba Complexes, south Brazil. In: S Am Symp Isot Geol, 1. Campos do Jordão. Ext Abstr, pp 134-136

Hartmann LA, Santos JO, Bossi J, Campal N, Schipilov A, McNaughton N (2002) Zircon and Titanite U-Pb SHRIMP geochronology of Neoproterozoic felsic magmatism on the eastern border of the Río de la Plata Craton, Uruguay. J S Am Earth Sci 15:229-236

Hasui Y, Carneiro CDR, Coimbra AM (1975) The Ribeira Fold Belt. Rev Bras Geoc 5:257-266

Heilbron M, Machado N (2003) Timing of terrane accretion in the Neoproterozoic-Eopaleozoic Ribeira orogen (SE Brazil). Prec Res 125:87-112

Heilbron M, Valeriano CM, Valladares CS, Machado N (1995) A Orogênese Brasiliana no segmento central da Faixa Ribeira, Brasil. Rev Bras Geoc 25:249-266

Heilbron M, Duarte BP, Nogueira JR (1998) The Juiz de Fora complex of the Central Ribeira belt, SE Brazil: a segment of Palaeoproterozoic granulitic crust thusted during the Pan-African Orogen. Gond Res 1:373-382

Heilbron M, Mohriak W, Valeriano CM, Milani EJ, Alemida J, Tupinambá M (2000) From collision to extension: the roots of the southeastern continental margin of Brazil. In: Mohriak W, Talwani M (eds) Atlantic Rifts and Continental Margins, vol 115. Am Geophy Un Geophys Monograph, pp 1-31

Heilbron M, Pedrosa-Soares AC, Campos Neto MC, Silva LC, Trouw RAJ, Janasi VC (2004) A província mantiqueira. In: MantessoNeto V, Bartorelli A, Carneiro CDR, Brito Neves BB (eds) O Desvendar de um Continente: a moderna geologia da América do Sul e o Legado da Obra de Fernando Flávio Marques de Almeida. Ed. Beca, São Paulo, pp 203-234

Hervé F, Godoy E, Parada MA, Ramos V, Rapela C, Mpodozis SC, Davidson J (1987) A general view on the Chilean-Argentine Andes, with emphasis on their early history. In: Monger JWH, Francheteau $\mathrm{J}$ (eds) Circum-Pacific orogenic Belts and the evolution of the Pacific Ocean Basin. Am Geophys Un, Boulder, pp $97-114$

Hippertt J, Rocha A, Lana C, Egydio-Silva M, Takeshita T (2001) Quartz plastic segregation and ribbon development in high-grade striped gneisses. J Struct Geol 23:67-80

Hongn FD, Hippertt JF (2001) Quartz crystallographic and morphologic fabrics during folding/transposition in mylonites. J Struct Geol 23:81-92 
Jacobs J, Thomas RT (2004) Himalayan-type indenter-escape tectonics model for the southern part of the late Neoproterozoic-early Paleozoic East African-Antarctic orogen. Geology 32:721-724

Janasi VA, Leite RJ, Van Schmus WR (2001) U-Pb chronostratigraphy of the granitic magmatism in the Agudos Grandes Batholith (west of São Paulo, Brazil): implications for the evolution of the Ribeira Belt. J S Am Earth Sci 14:363-376

Janasi VA, Alves A, Vlach SRF, Leite RJ (2003) Granitos Peraluminosos da Porção Central da Faixa Ribeira, Estado de São Paulo: Sucessivos Eventos de Reciclagem da Crosta Continental no Neoproterozóico. Geol USP Sér Cient 3:13-24

Jezek J, Schulmann K, Thompson AB (2002) Strain partitioning in front of an obliquely convergent indenter. EGU Stephan Mueller Special Publ Ser 1:93-104

Jost H, Frantz JC, Brod JA (1984) Revisão da Tipologia, Cronologia e Significado Geotectbnico dos Falhamentos do Escudo Sul-riograndense. In: Cong Bras Geol, 33. Rio de Janeiro, Anais, vol 3, pp 1707-1720

Koester E, Soliani E Jr, Fernandes LAD, Kraemer G, Tommasi A (1997) Geocronologia $\mathrm{Rb} / \mathrm{Sr}$ e K/Ar dos granitóides sintectônicos à Zona de Cisalhamento Transcorrente Dorsal de Canguçu na região de Encruzilhada do Sul (RS). Pesquisas 24:67-77

Kohn BP, Gleadow AJW, Brown RW, Gallagher K, O'sullivan PB, Foster DA (2002) Shaping the Australian crust over the last 300 million years: insights from fission track thermotectonic imaging and denudation studies of key terranes. Austr J Earth Sci 49:697-717

Leite JD, Hartmann LA, Mcnaughton N, Chemalle F Jr (1998) Shrimp U-Pb zircon geochronology of Neoproterozoic juvenile and crustal reworked terranes in southernmost Brazil. Internat Geol Rev 40:688-705

Machado R, Endo I (1993) Estruturas transcorrentes na borda sul do Cráton do São Francisco. In: Simp sobre o Cráton de São Francisco, 2, Salvador, Anais, pp 269-271

Machado R, Endo IS (1994) Superposição cinemática Brasiliana no cinturão de cisalhamento Atlântico e na Cunha de Guaxupé. In: Cong Bras Geol 38, Camboriú, Anais, pp 269-270

Machado N, Valladares C, Heilbron M, Valeriano C (1996) U-Pb geochronology of the central Ribeira belt (Brazil) and implications for the evolution of the Brazilian Orogeny. Prec Res 79:347-361

Mallmann G, Chemale F Jr, Morales LFG (2004) Evolução estrutural da porção sul do Terreno Nico Pérez, Uruguai: registro da convergência entre as placas Rio de La Plata e Kalahari no final do Neoproterozóico. Rev Bras Geoc 34:201-212

Mantovani MSM, Brito Neves BB (2005) The Paranapanema Lithospheric Block: its importance for Proterozoic (Rodinia, Gondwana) Supercontinent Theories. Gond Res 8:303-315

Mantovani MSM, Shukowsky W, Basei MAS, Vasconcelos ACBC (1989) Modelo gravimétrico das principais descontinuidades crustais nos terrenos Pré-Cambrianos dos Estados do Paraná e Santa Catarina. Rev Bras Geoc 19:367-374

McDougall I, Harrison TM (1999) Geochronology and Thermochronology by the ${ }^{40} \mathrm{Ar} /{ }^{39} \mathrm{Ar}$ method. Oxford University Press, London, p 269

Mégard F (1987) Cordilheiran Andes and Marginal Andes: a review of Andean Geology north of Anca elbow. In: Monger JWH, Francheteau J (eds) Circum-Pacific orogenic Belts and the evolution ofthe Pacific Ocean Basin. Am Geophys Un, Boulder, pp 71-96

Mendes JC, Ávila CA, Pereira RM, Heilbron MPL, Moura CAV (2006) ${ }^{207} \mathrm{~Pb} /{ }^{206} \mathrm{~Pb}$-ages of zircons from syn-collisional I-type porphyritic granites of the central Ribeira belt, SE Brazil. Gond Res 9:326-336
Molnar P, Tapponnier P (1975) Cenozoic tectonics of Asia, effects of a continental collision. Science 189:419-426

Nardi LVS, Frantz JC (1995) The Cordilheira Suite: late Proterozoic peraluminous granitoids from the Southern Brazil. J S Am Earth Sci 8:55-63

Oyhantçabal P, Siegemund S, Wemmer K, Frei R, Layer P (2007) Post-collisional transition from calc-alkaline to alkaline magmatism during transcurrent deformation in the southernmost Dom Feliciano Belt (Braziliano-Pan-African, Uruguay). Lithos 98:141-159

Oyhantçabal P, Siegesmund S, Wemmer K, Layer P (2009a) The Sierra Ballena Shear Zone in the southernmost Dom Feliciano Belt (Uruguay): evolution, kinematics, and deformation conditions. Int J Earth Sci (Geol Rundsch). doi:10.1007/s00531009-0453-1

Oyhantçabal P, Siegesmund S, Wemmer K, Presnyakov S, Layer P (2009b) Geochronological constraints on the evolution of the southern Dom Feliciano Belt (Uruguay). J Geol Soc Lond 166:1075-1084

Oyhantçabal P, Siegesmund S, Wemmer K, Passchier, CW (2010) The transpressional connection between Dom Feliciano and Kaoko belts at 580-550 Ma. Int J Earth Sci (this volume)

Passarelli CR (2001) Caracterização estrutural e geocronológica dos domínios tectônicos da porção sul-oriental do Estado de São Paulo. PhD Thesis, University of São Paulo

Passarelli CR, Basei MAS, Campos Neto MC (1993) Caracterização geométrica e cinemática da Zona de Cisalhamento Major Gercino e sua importância na compartimentação dos terrenos Pré-Cambrianos de Santa Catarina. Rev Bras Geoc 23:234-241

Passarelli CR, Basei MAS, Ahrendt H, Wemmer K, Siga O Jr (1997) Geochronological evolution of Major Gercino shear zone, south Brazil. In: S Am Symp Isot Geol 1, Campos de Jordão. Extended Abstracts, pp 231-233

Passarelli CR, Prazeres Filho HJ, Siga O Jr, Basei, MAS, Campos Neto MC (2003) Geocronology and isotope geology of the Precambrian Terranes of southeastern São Paulo State, Brazil. In: S Am Symp Isot Geol 4, Salvador. Short Papers 2, pp 635-638

Passarelli CR, Basei MAS, Campos Neto MC, Siga O Jr, Prazeres Filho HJ (2004a) a Geocronologia e geologia isotópica dos terrenos Pré-Cambrianos da porção sul-oriental do Estado de São Paulo. Geol USP Sér Cient 4:55-74

Passarelli CR, Basei, MAS, Prazeres Filho HJ, Siga O Jr (2004b) The Cubatão-Itariri Shear System and the Serrinha Shear Zone: the limits of the Pre-Cambrian Terranes, southeastern São Paulo State-Brazil. In: Intern Geol Congr 32. CD

Passarelli CR, Basei MAS, Prazeres Filho HJ, Siga O Jr, Campos Neto MC (2005) Caracterização estrutural das fases de deformação identificadas no Sistema de Cisalhamento CubatãoItariri, SE do Estado de São Paulo. In: Simp Nac Est Tect 10, Curitiba. Boletim de Resumos Expandidos, pp 349-352

Passarelli CR, Basei MAS, Wemmer K, Mc Reath I, Siga O Jr (2006) Calc-alkaline to alkaline syntectonic granites of the Major Gercino Shear Zone, Santa Catarina State, Brazil. In: S Am Symp Isot Geol 5. Punta Del Este, Uruguay, 2006. Short Papers, Crustal Evolution of South América, pp 151-154

Passarelli CR, Basei MAS, Prazeres Filho HJ, Siga O Jr, Szabó GAJ, Marco-Neto J (2007) Structural and geochronological constraints on the evolution of the Juréia Massif, Registro Domain, State of São Paulo, Brazil. An Acad Bras Ciênc 79:441-455

Passarelli CR, Wemmer K, Siga O Jr, Siegesmund S, Basei MAS (2008) Tectonothermal evolution of the SE São Paulo State Precambrian terranes. In: S Am Symp Isot Geol 6. San Carlos de Bariloche, Argentina, 2008. Book of Abstracts, pp 150

Passarelli CR, Basei MAS, Siga O Jr, Sato K, Sproesser WM, Loios VAP (2009) Dating minerals by ID-TIMS geochronology at 
times of in situ analysis: selected case studies from the CPGeoIGc-USP laboratory. An Acad Bras Ciênc 81:1-25

Passarelli CR, Basei MAS, Siga O Jr, Mc Reath I, Campos Neto MC (2010) Deformation and geochronology of syntectonic granitoids emplaced in the Major Gercino Shear Zone, southeastern South America. Gond Res (article in press). doi: 10.1016/j.gr.2009.09.013

Pedrosa-Soares AC, Wiedmann-Leonardos CM (2000) Evolution of the Araçuaí Belt and its connections to the Ribeira Belt. In: Cordani UG, Thomaz Filho A, Campos, DA (eds) Tectonic evolution of South America, Rio de Janeiro, 31 IGC, pp 265-268

Peltzer G, Tapponnier P (1988) Formation and evolution of strike-slip faults, rifts, and basins during India-Asia collision: an experimental approach. J Geophys Res 93B: 15 085-15 117

Philipp RP, Machado R (2005) The Late Neoproterozoic granitoid magmatism of the Pelotas Batholith, southern Brazil. J S Am Earth Sci 19:461-478

Philipp RP, Machado R, Chemale F Jr (2003) Reavaliação e Novos Dados Geocronológicos ( $\mathrm{Ar} / \mathrm{Ar}, \mathrm{Rb} / \mathrm{Sr}$ e $\mathrm{Sm} / \mathrm{Nd}$ ) do Batólito Pelotas no Rio Grande do Sul: Implicações Petrogenéticas e Idade de Reativação das Zonas de Cisalhamento. Geol USP Sér Cient 3:71-84

Philipp RP, Mallmann G, Bitencourt MF, Souza ER, Souza MMA, Liz JD, Wild F, Arendt S, Oliveira AS, Duarte L, Rivera CB, Prado M (2004) Caracterização litológica e evolução metamórfica da porção leste do Complexo Metamórfico Brusque, Santa Catarina. Rev Bras Geoc 34:21-34

Picada RS (1971) Ensaio sobre a tectônica do Escudo Sul-RioGrandense. Caracterização dos sistemas de falhas. In: Congr Bras Geol, 25. São Paulo. Anais, vol 1, pp 167-191

Picha FJ (2002) Late orogenic strike-slip faulting and escape tectonics in frontal Dinarides-Hellenides, Croatia, Yugoslavia, Albania, and Greece. AAPG Bull 86:1659-1671

Pierin ARH, Rostirolla SP, Mancini F, Romeiro MT, Spisila AL (2009). Análise Estrutural Multi-Escala na Porção Sudoeste do Sistema de Cisalhamento Lancinha, em Balsa Nova-PR. In: Simp Nac Est Tect 12. Ouro Preto, Brazil, 2009. In: Simpósio Nacional de Estudos Tectônicos, 12, International Symposium on Tectonicas, 2009, Ouro Preto. Programa \& Resumos SNET2009, vol 1, pp. 26-26

Porada H (1979) The Damara-Ribeira orogen of the Pan-AfricanBraziliano cycle in Namibia (southwest Africa) and Brazil as interpreted in terms of continental collision. Tectonophysics 57:237-265

Prazeres Filho HJ, Harara OMM, Basei MAS, Passarelli CR, Siga O $\mathrm{Jr}$ (2003) Litoquímica, geocronologia U-Pb e geologia isotópica $(\mathrm{Sr}-\mathrm{Nd}-\mathrm{Pb})$ das rochas graníticas dos batólitos Cunhaporanga e Três Córregos na Porção Sul do Cinturão Ribeira, Estado do Paraná. Geol USP Sér Cient 3:51-70

Preciozzi F, Masquelin H, Sanchez-Bettucci L (1993) Geologia de la Porción sur del Cinturón Cuchilla de Dionisio. In: Simp Int Neoprot-Cambrico Cuenca del Plata Field guide, 1, Montevideo, pp 1-39

Preciozzi F, Peel E, Muzio R, Ledesma JJ, Guerequiz R (2001) Dom Feliciano Belt and Punta del EsteTerrane: geochronological features. In: S Am Symp Isot Geol 3, Pucón, Chile. Ext Abstr, pp 217-220

Ramos VA, Aleman A (2000) Tectonic Evolution of the Andes. In: Cordani UG, Milani EJ, Thomaz Filho A, Campos DA (eds) Tectonic evolution of South America. Rio de Janeiro, pp 635-685

Ratschbacher L, Frisch W, Linzer H, Merle O (1991) Lateral extrusion in the eastern Alps, part II: structural analysis. Tecton $10: 257-271$

Riccomini C, Peloggia AUG, Saloni JCL, Kohnke MW, Figueira RM (1989) Neotectonic activity in the Serra do Mar rift system (southeastern Brazil). J S Am Earth Sci 2:191-197
Sadowski GR (1984) Estado da Arte do Tema: geologia estrutural de grandes falhamentos. In: Congr Bras Geol 33, Rio de Janeiro. Anais vol 4, pp 1767-1793

Sadowski GR (1991) A Megafalha de Cubatão no sudeste brasileiro. Bol. IG-USP Sér Cient 22:15-28

Sadowski GR, Motidome MJ (1987) Brazilian Megafaults. Rev Geol Chile 31:61-75

Sadowski GR, Dias Neto CM, Silva ME (1978) Análise do Fraturamento do Maciço de Itatins, Estado de São Paulo. In: Congr Bras Geol 30, Recife. Anais, Bol 1, pp 60

Salamuni E (1995) Dobramentos e redobramentos na porção sul da Zona de Cisalhamento Lancinha-Cubatão. In: Simp Nac Est Tect 5, Gramado. Bol Res Exp, pp 78-80

Salamuni E, Fiori AP, Wernick E (1993) Características estruturais e evolução tectônica do Núcleo Betara a Norte de Curitiba (PR). Bol Paran Geoc 41:91-124

Schmitt RS, Trouw RAJ, Van Schmus WR, Pimentel MM (2004) Late amalgamation in the central part of Western Gondwana: new geochronological data and the characterization of a Cambrian collision orogeny in the Ribeira belt (SE Brazil). Prec Res 133:29-61

Sengor AMC, Gorur N, Saroglu F (1985) Strike-slip faulting and related basin formation in zones of tectonic escape: Turkey as a case study. In: Biddle KD, Christie-Blick N (eds) Strike-slip deformation, basin formation, and sedimentation. SEPM Spec. Publ. 17, pp 227-264

Siga O Jr, Basei MAS, Reis Neto JM, Harara OMM, Passarelli CR. Prazeres Filho HJ, Weber W, Machiavelli A (1997) Ages and tectonic setting of alkaline-peralkaline granitoids of Paraná and Santa Catarina states, southern Brazil. In: S Am Symp Isot Geol, 1. Campos do Jordão, Short Papers, pp 301-303

Siga O Jr, Basei MAS, Machiavelli A (1993) Evolução geotectônica da porção NE de Santa Catarina e SE do Paraná, com base em interpretações geocronológicas. Rev Bras Geoc 23:215-223

Siga O Jr, Basei MAS, Passarelli CR, Sato K, Cury LF, Mcreath I (2009) Lower and Upper Neoproterozoic magmatic records in Itaiacoca Belt (Paraná-Brazil): Zircon ages and lithostratigraphy studies. Gond Res 15:197-208

Silva LC (1991) O Cinturão Metavulcanossedimentar Brusque e a evolução policíclica das faixas dobradas Proterozóicas no sul do Brasil: uma revisão. Rev Bras Geoc 21:60-73

Silva ATSF, Francisconi O, Godoy AM, Batolla F Jr (1981) Projeto Integração e detalhe geológico no Vale do Ribeira, Relatório Final. Integração Geológica, São Paulo, p 15v

Silva LC, Mcnaughton NJ, Hartmann LA, Fletcher IR (2003) Zircon U-Pb SHRIMP dating of The Serra dos Órgãos and Rio de Janeiro Gneissic Granitic Suites: implications for the (560 Ma) Brasiliano/Pan-African Collage*. Rev Bras Geoc $33: 237-244$

Silva LC, McNaughton NJ, Armstrong R, Hartmann LA, Fletcher IR (2005a) The neoproterozoic Mantiqueira Province and its African connections: a zircon-based U-Pb geochronologic subdivision for the Brasiliano/Pan-African systems of orogens. Prec Res 136:203-240

Silva LC, McNaughton NJ, Fletcher IR (2005b) SHRIMP U-Pb zircon geochronology of Neoproterozoic crustal granitoids (Southern Brazil): a case for discrimination of emplacement and inherited ages. Lithos 82:503-526

Soares PC (1987) Seqüências tectono-sedimentares e tectônica deformadora no centro-oeste do Escudo Paranaense. In: Simp Sul Bras Geol 3. Curitiba, Atas, vol 2, pp 743-771

Soliani E Jr (1986) Os dados geocronológicos do Escudo Sul-riograndense e suas implicações de ordem geotectônica. PhD Thesis, University of São Paulo

Sollner F, Trouw RAJ (1997) The Andrelândia depositional cycle (Minas Gerais), a post-tranzamazonic sequence South of São 
Francisco craton: evidence from U-Pb dating on zircons of a metasediment. J S Am Earth Sci 10:21-28

Stern C, Kilian R (1996) Role of the subducted slab, mantle wedge and continental crust in the generation of adakites from the Andean Austral Volcanic Zone. Contrib Miner Petrol 123:263-281

Tapponnier P, Peltzer G, Le Dain AY, Armijo R, Cobbold P (1982) Propagating extrusion tectonics in Asia: new insights from simple experiments with plasticine. Geology 10:611-616

Tello Sáenz CA, Hackspacher PC, Hadler Neto JC, Iunes PJ, Guedes OS, Paulo RS, Ribeiro BLF (2003) Recognition of Cretaceus, Paleocene and Neogene Tectonic Reactivation, through Apatite Fission-Track Analysis, in Precambrian areas of the Southeast Brazil: association with the South Atlantic Ocean Opening. J S Am Earth Sci 15:765-774

Tikoff B, Teyssier CH (1994) Strain modelling of displacement field partitioning in transpressional orogens. J Struct Geol 16:1575-1588

Tomljenovic B, Csontos L, Márton E, Márton P (2008) Tectonic evolution of the northwestern Internal Dinarides as constrained by structures ans rotation of Medvednica Mountains, North Croatia. In: Siegesmund S, Fügenschuh B, Froitzheim N (eds) Tectonic aspects of the Alpine-Dinaride-Carpathian System. Geol Soc, London. Spec Publ 298, pp 145-167

Trainini DR, Dias AA, Krebs ASJ, Souza EC, Capeletti I, Toniolo JA, Silva LC, Silva MAS (1978) DNPM/CPRM. Projeto Vidal Ramos-Biguaçu. Porto Alegre, 303 pp

Trompette RR (1994) Geology of Western Gondwana 2000-500 Ma: The Pan-African-Brasiliano amalgamation of South America and adjacent Africa. Rotterdam, Balkema

Trouw R, Heilbron M, Ribeiro A, Paciullo F, Valeriano CM, Almeida JCH, Tupinambá M, Andreis RR (2000) The central segment of the Ribeira Belt. In: Cordani UG, Milani EJ, Thomaz Filho A, Campos, DA (eds) Tectonic evolution of South America. Rio de Janeiro, pp 287-310

Tupinambá M, Teixeira W, Heilbron M (2000) Neoproterozoic Western Gondwana assembly and subduction-related plutonism: the role of the Rio Negro Complex in the Ribeira belt, Southeastern Brazil. Rev Bras Geoc 30:7-11
Tupinambá M, Heilbron M, Duarte BP, Nogueira JR, Valladares C, Almeida J, Silva LGE, Medeiros SR, Almeida CG, Miranda A, Ragatky CD, Mendes J, Ludka I (2007) Geologia da Faixa Ribeira Setentrional: Estado da Arte e Conexões com a Faixa Araçuaí. Geon 15:67-79

Vauchez A, Tommasi A, Egydio-Silva M (1994) Self-indentation of continental lithosphere. Geology 22:967-970

Vauchez A, Egydio-Silva M, Babinski M, Tommasi A, Uhlein A, Liu D (2007) Deformation of a pervasively molten middle crust: insights from the neoproterozoic Ribeira-Araçuaí orogen (SE Brazil). Terra Nova 19:278-286

Vlach SRF (2001) Microprobe monazite constraits for an early (ca. $790 \mathrm{Ma})$ Brasiliano orogeny: the Embu Terrane, Southeastern Brazil. In: S Am Symp Isot Geol 3, Pucón. Extd Abstr, pp 265-268

Weber W, Siga O Jr, Sato K, Reis Neto JM, Basei MAS, Nutman AP (2004) A Formação Água Clara na Região de Araçaíba-SP: Registro U-Pb de uma Bacia Mesoproterozóica. Geol USP Sér Cient 4:101-110

Wemmer K (1991) K/Ar-Altersbestimmungsmöglichkeiten für retrograde deformations-prozesse im spröden und duktilen BereichBeispiele aus der KTB-Vorbohrung (Oberpfalz) und dem Bereich der Insubrischen Linie (N-Italien). Göttinger Arbeiten Geologie Paläontologie 51:1-61

Willigers BJA, Krogstad EJ, Wijbrans JR (2001) Comparison of thermochronometers in a slowly cooled granulite terrain: Nagssugtoqidian Orogen, West Greenland. J Petrol 42:1729-1749

Woodcock NH (1986) The role of strike-slip fault systems at plate boundaries. Philosoph Transact Royal Soc Lond A317:13-29

Yeats RS, Lillie RJ (1991) Contemporary tectonics of the Himalayan frontal fault system: folds, blind thrusts and the 1905 Kangra earthquake. J Struct Geol 13:215-225

Zalán PPV, Oliveira JAB (2005) Origem e evolução estrutural do sistema de rifts cenozóicos do Sudeste do Brasil. Bol Geoc Petrobrás 13:269-300

Zhang X, Wang Y (2007) Seismic and GPS evidence for the kinematics and the state of stress of active structures in south and south-central Tibetan Plateau. J Asian Earth Sci 29:283-295 